\title{
Nanophosphorus Fertilizer Stimulates Growth and Photosynthetic Activity and Improves P Status in Rice
}

\author{
Erika Miranda-Villagómez, ${ }^{1}$ Libia Iris Trejo-Téllez ${ }^{\mathbb{D}},{ }^{1}$ Fernando Carlos Gómez-Merino ${ }^{\mathbb{D}}{ }^{1}$ \\ Manuel Sandoval-Villa, ${ }^{1}$ Prometeo Sánchez-García, ${ }^{1}$ and Miguel Ángel Aguilar-Méndez ${ }^{2}$ \\ ${ }^{1}$ Department of Soil Science. Laboratory of Plant Nutrition. College of Postgraduates, Campus Montecillo, 56230 Montecillo, Mexico \\ ${ }^{2}$ Centro de Investigación en Ciencia Aplicada y Tecnología Avanzada, Unidad Legaria, Instituto Politécnico Nacional, \\ 11500 Ciudad de México, Mexico
}

Correspondence should be addressed to Libia Iris Trejo-Téllez; tlibia@colpos.mx

and Fernando Carlos Gómez-Merino; fernandg@colpos.mx

Received 18 July 2019; Accepted 11 October 2019; Published 18 November 2019

Academic Editor: Hassan Karimi-Maleh

Copyright (c) 2019 Erika Miranda-Villagómez et al. This is an open access article distributed under the Creative Commons Attribution License, which permits unrestricted use, distribution, and reproduction in any medium, provided the original work is properly cited.

\begin{abstract}
The efficiency of nanoparticles covered with type A gel and loaded with $\mathrm{KH}_{2} \mathrm{PO}_{4}$, as a source of $\mathrm{P}$, was evaluated on growth, phosphorus concentration and accumulation, and photosynthesis-related parameters in rice plants (Oryza sativa L. ssp. indica) cv. Morelos A-2010, under greenhouse conditions. Plants were treated for 14 days with $\mathrm{P}$ concentrations equivalent to 50 and $100 \%$ of those established in the Yoshida nutrient solution. Sources of $\mathrm{P}$ were $\mathrm{KH}_{2} \mathrm{PO}_{4}$, nano- $\mathrm{KH}_{2} \mathrm{PO}_{4}$, and nano- $\mathrm{KH}_{2} \mathrm{PO}_{4}$ with trypsin; control treatments were distilled water and nanoparticles with type A gel. The solutions were renewed every $7 \mathrm{~d}$. Rice plants exhibited differential $\mathrm{P}$ absorption in function of the $\mathrm{P}$ source tested. $\mathrm{P}$ supplied by $\mathrm{KH}_{2} \mathrm{PO}_{4}$ had a higher uptake rate than $\mathrm{P}$ supplied by nano- $\mathrm{KH}_{2} \mathrm{PO}_{4}$, alone or with trypsin. Nevertheless, nano- $\mathrm{KH}_{2} \mathrm{PO}_{4}$ promoted higher physiological efficiency for $\mathrm{P}$ in both roots and shoots, which consequently induced higher biomass accumulation in these organs. $\mathrm{P}$ concentration in shoots, as well as $\mathrm{P}$ accumulation in shoots and roots, were positively correlated with the photosynthetic rate. Also, nano$\mathrm{KH}_{2} \mathrm{PO}_{4}$ increased instant water use efficiency in rice plants.
\end{abstract}

\section{Introduction}

The use of nanotechnology in agriculture comprises the controlled release of certain substances, mainly pesticides and fertilizers. Nonetheless, uptake and use efficiency, as well as the effects of the nanoparticles on growth and metabolic functions in plants, vary between genotypes [1].

Nanoparticles loaded with nutrients can enter root cells using different internationalization routes including joining to transport proteins through aquaporins and ionic channels, creating new pores, and by endocytosis [2]. In several plant species, carbon-coated nanoparticles can translocate in the whole plant to different tissues and organs. Indeed, transport of nanoparticles in the roots happens from one cell to the next via plasmodesmata [3].
Most research on nanofertilizers have been done with metallic nutrients like $\mathrm{Cu}, \mathrm{Mn}, \mathrm{Zn}$, and $\mathrm{Fe}$ [4]. Also, $\mathrm{Al}, \mathrm{Ce}$, $\mathrm{La}$, and $\mathrm{Ti}$ among other beneficial elements [5] have been tested as nanoparticles in plants [6]. Consequently, during the last decade, metal nanoparticle production has grown exponentially, with a global production expected to reach 58,000 metric tons by the year 2020 [7]. In contrast, research on macronutrients is limited, although these elements drive global crop production [8]. Among macronutrients, phosphorus $(\mathrm{P})$ deficiency is a common factor hindering yield and crop quality worldwide [9].

Phosphorus (P) is part of amino acids, nucleic acids, phospholipids, and high-energy molecules such as adenosine triphosphate (ATP) [10] in all living organisms. In plants, P is an essential element required for development and 
reproduction, and it is one of the main components of the fertilizers necessary to sustain modern agriculture. In soils, the concentration of inorganic $\mathrm{P}$ (available to plants) ranges from 35 to $70 \%$ of the total $\mathrm{P}$. This form of $\mathrm{P}$ shows low diffusion and high fixation rates in soils through ligand exchange by 1 : 1 clay minerals, Fe and $\mathrm{Al}$ oxides and hydroxides, and is thus precipitated as $\mathrm{Fe}, \mathrm{Al}$, and $\mathrm{Ca}$ phosphates $[11,12]$. Additionally, phosphate fertilizers are obtained from phosphoric rock, a nonrenewable resource, and whose reserves are running out [13]. Consequently, the importance of promoting the efficiency of $\mathrm{P}$ uptake and use in agricultural crops like rice becomes evident, while supplying nanofertilizers with phosphorus represents an alternative.

Rice is the second most consumed cereal worldwide, being the basic foodstuff for more than $40 \%$ of the population [14]. In the coming years, a production of 8 to 10 million tons annually will be required. Without expanding the agricultural land surface, this will require a mean increase in yields of $0.6 \mathrm{tha}^{-1}$, around the world [15]. In order to fulfill this demand, it is crucial to find greater efficiency in the uptake and use of primary fertilizers, including $\mathrm{P}$, and consequently, depending less on copious applications of fertilizers to the crops, and rather search for sustainable agricultural production [16]. In Mexico, the Morelos rice cultivar displays unique agronomical, milling, and culinary characteristics, which have placed it as one of the highest quality rice varieties, both nationally and internationally [14].

The present study was carried out aiming at evaluating the effect of a phosphate nanofertilizer on growth, physiological, and nutrimental parameters of rice plants during their vegetative stage in hydroponics. The nutrient solution did not contain any other nutrient, in order to discard effects from the interactions of the nanophosphorus fertilizer with other nutrient sources. $\mathrm{P}$ was chosen since, as mentioned before, its deficiency is a common factor that limits crop production at a global scale.

This objective was based on the hypothesis that the performance of the phosphorous nanofertilizer in plants is dependent on the characteristics and properties of the medium to which it is added. The $\mathrm{P}$ concentration of the Yoshida nutrient solution $\left(0.383 \mathrm{~mol}_{(+)} \mathrm{m}^{-3}\right)$ was used as reference, which was generated specifically for rice crops [17].

\section{Materials and Methods}

2.1. Location of the Experiment and Plant Material. The experiment was set up in a saw tooth type greenhouse. Rice (Oryza sativa L. ssp. indica) cultivar Morelos A-2010 seeds were used [18]. Rice seeds were disinfected with $70 \%$ ethanol for $5 \mathrm{~min}$ and $3 \%$ sodium hypochlorite for $30 \mathrm{~min}$. Subsequently, seeds were rinsed with distilled water and dried on an absorbent paper. Once dried, they were germinated in the MS medium [19], supplemented with sucrose (3\%) and agar $(0.8 \%)$.

2.2. Establishment of the Experiment. Twelve days after sowing the seeds, seedlings were transplanted into $5 \mathrm{~L}$ recipients containing the Yoshida nutrient solution [17] at 50\% concentration $\left(0.715 \mathrm{mM} \quad \mathrm{NH}_{4} \mathrm{NO}_{3}, \quad 0.500 \mathrm{mM} \quad \mathrm{CaCl}_{2} \quad 2 \mathrm{H}_{2} \mathrm{O}\right.$,
TABLE 1: Evaluated treatments in rice plants cv. Morelos A-2010.

\begin{tabular}{lc}
\hline Treatment & Description \\
\hline 1 & Distilled water \\
2 & Polymer $^{\mathrm{a}}\left(0.1042 \mathrm{~g} \mathrm{~L}^{-1}\right)$ \\
3 & $50 \%^{\mathrm{b}} \mathrm{P}$ from $\mathrm{KH}_{2} \mathrm{PO}_{4}\left(0.0260 \mathrm{~g} \mathrm{~L}^{-1}\right)$ \\
4 & $100 \%^{\mathrm{b}} \mathrm{P}$ from $\mathrm{KH}_{2} \mathrm{PO}_{4}\left(0.0521 \mathrm{~g} \mathrm{~L}^{-1}\right)$ \\
5 & $50{ }^{\mathrm{b}} \mathrm{P}$ from nano- $\mathrm{KH}_{2} \mathrm{PO}_{4}\left(0.0781 \mathrm{~g} \mathrm{~L}^{-1}\right)$ \\
6 & $100 \%^{\mathrm{b}} \mathrm{P}$ from nano- $\mathrm{KH}_{2} \mathrm{PO}_{4}\left(0.1563 \mathrm{~g} \mathrm{~L}^{-1}\right)$ \\
7 & $50{ }^{\mathrm{b}} \mathrm{P}$ from nano- $\mathrm{KH}_{2} \mathrm{PO}_{4}\left(0.0781 \mathrm{gL}^{-1}\right)$ \\
& with trypsin $\left(0.1 \mathrm{mg} \mathrm{L}^{-1}\right)$ \\
8 & $100 \%{ }^{\mathrm{b}} \mathrm{P}$ from nano- $\mathrm{KH}_{2} \mathrm{PO}_{4}\left(0.1563 \mathrm{~g} \mathrm{~L}^{-1}\right)$ \\
\hline
\end{tabular}

a Polymer: type A gel nanoparticles; ${ }^{\mathrm{b}}$ percentage of $\mathrm{P}$ concentration of the Yoshida nutrient solution. Concentration of $\mathrm{P}$ in the Yoshida nutrient solution at $100 \%=0.383 \mathrm{~mol}_{(+)} \mathrm{m}^{-3}$.

$0.820 \mathrm{mM} \mathrm{MgSO}_{4} 7 \mathrm{H}_{2} \mathrm{O}, 0.660 \mathrm{~K}_{2} \mathrm{SO}_{4}, 0.192 \mathrm{mM} \mathrm{NaH}_{2} \mathrm{PO}_{4}$, $3.995 \mu \mathrm{M} \mathrm{MnCl}_{2} 4 \mathrm{H}_{2} \mathrm{O}, 0.075 \mu \mathrm{M} \mathrm{ZnSO}_{4} 7 \mathrm{H}_{2} \mathrm{O}, 0.075 \mu \mathrm{M}$ $\mathrm{CuSO}_{4} 7 \mathrm{H}_{2} \mathrm{O}, 0.038 \mu \mathrm{M}\left(\mathrm{NH}_{4}\right)_{6} \mathrm{Mo}_{7} \mathrm{O}_{24}, 0.695 \mu \mathrm{M} \mathrm{H}_{3} \mathrm{BO}_{3}$, and $1 \mathrm{mM}$ Fe-EDTA). The nutrient solution was prepared using distilled water and analytical grade reagents (JT Baker; Phillipsburg, NJ, USA). Fe-EDTA was supplied by SigmaAldrich (St. Louis, MO, USA). In each $5 \mathrm{~L}$ recipient, eight seedlings were established. The $\mathrm{pH}$ of the nutrient solution was adjusted to 5.5-6.0, and it was renewed every seven days. Seedlings were kept under these conditions for 30 days as the acclimatization period. After the acclimatization period in hydroponics, plants were kept for $7 \mathrm{~d}$ in the $50 \%$ Yoshida nutrient solution with no $\mathrm{P}$.

2.3. Evaluated Treatments. The evaluated treatments are shown in Table 1. Treatment applications iniciated after a $7 \mathrm{~d}$ period without $\mathrm{P}$ (37 days after transplanting), using rice plants with a mean height of $32.5 \mathrm{~cm}$. Treatments 1 and 2 were our negative controls (i.e., they contain no P). Treatment 2 consisted of adding type A gel (obtained through acid hydrolysis); this polymer is used for the synthesis of the nanoparticles evaluated in treatments 5 to 8 . Treatments 3 and 4 contained 50 and $100 \%$ of the $\mathrm{P}$ concentration described in the Yoshida solution $\left(0.1915\right.$ and $\left.0.3830 \mathrm{~mol}_{(+)} \mathrm{m}^{-3}\right)$, respectively, using $\mathrm{KH}_{2} \mathrm{PO}_{4}$ (JT Baker) as a source of $\mathrm{P}$. Treatments 5 and 6 also contained 50 and $100 \%$ of the $\mathrm{P}$ concentration of the Yoshida solution, but the source of $\mathrm{P}$ was nano- $\mathrm{KH}_{2} \mathrm{PO}_{4}$ covered with type A gel, synthesized according to MirandaVillagómez et al. [20]. Finally, treatments 7 and 8 consisted of $\mathrm{P}$ supplied from nano- $\mathrm{KH}_{2} \mathrm{PO}_{4}$ covered with type A gel, at 50 and $100 \%$, respectively, of the $\mathrm{P}$ concentration indicated in the Yoshida solution, with the addition of the enzyme trypsin (EC 3.4.21.4; proteolytic enzyme that catalyzes the hydrolytic rupture of the peptide bonds established between Arg and Lis), at concentrations 0.1 and $0.2 \mathrm{mg} \mathrm{L}^{-1}$, respectively.

\subsection{Evaluated Variables}

2.4.1. P Concentration in the Nutrient Solutions. In order to evaluate the reduction of $\mathrm{P}$ in the nutrient solutions, samples were taken from these solutions recently prepared 
(day 8 of the treatment phase) and after the period established for their renewal (day 14 of the treatment phase). After collecting the samples, they were filtered with medium-sized pore filter paper and acidified with $\mathrm{HNO}_{3}$ at $68 \%$ adding a $5 \mu \mathrm{L} \mathrm{HNO}_{3} \mathrm{~mL}^{-1}$ sample. The determination of $\mathrm{P}$ concentration was done through inductively coupled plasma-optical emission spectrometry (ICP-OES 725-ES Agilent ${ }^{\circledR}$, Mulgrave, Australia).

2.4.2. Plant Height and Number of Leaves and Tillers. Plant height was determined considering from the base to the tip of the longest leaf. Also, the number of leaves and the number of tillers were counted. These evaluations were done at 0,7 , and $14 \mathrm{~d}$ after beginning the treatments.

2.4.3. Photosynthesis-Related Variables. We evaluated the net instant photosynthesis rate, stomatal conductance, intercellular $\mathrm{CO}_{2}$ concentration, and leaf transpiration in rice, using a portable Infrared Gas Analyzer (IRGA) (LI-6400 ${ }^{\circledR}$, LI-COR Inc., Lincoln, NE, USA). The measurements were taken in all treatments $13 \mathrm{~d}$ after beginning the treatments, from 13:00 to $14: 30 \mathrm{~h}$.

2.4.4. Dry Biomass. Fourteen days after beginning the treatments, plants were divided into shoots and roots, and dried in a forced air convection oven at $70^{\circ} \mathrm{C}$ (HCF125, Riossa, Monterrey, Nuevo León, Mexico) for $48 \mathrm{~h}$. Subsequently, the dry biomass weight was evaluated using an analytical balance (Adventurer Pro AV213C, OHAUS, Parsippany, NJ, USA).

2.4.5. $P$ Concentration. Nutrient concentration was estimated in the dry tissue of shoots and roots. The determination of the $\mathrm{P}$ concentration was done on the extracts resulting from the digestion of the dry plant material $\left(\mathrm{HNO}_{3}: \mathrm{HClO}_{4}, 2: 1, v: v, 180^{\circ} \mathrm{C}, 21 \mathrm{~h}\right)$, using the ICPOES 725-ES Agilent equipment.

2.5. Statistical Analysis. Experimental data were analyzed with the SAS ver. 9.4 statistical software [21], for a completely randomized experimental design. The analysis of variance and mean comparison was done with the LSD test at a significance level of $95 \%$.

\section{Results and Discussion}

3.1. P Reduction in the Nutrient Solutions. At day 7 after treatment application (dat), in the nutrient solutions containing 50\% P of the Yoshida solution (treatments 3, 5, and 7 ), all of $\mathrm{P}$ supplied had been absorbed by the plants, independent of the source of $\mathrm{P}$ used. On the other hand, after $7 \mathrm{~d}$, the solutions with $100 \%$ of the $\mathrm{P}$ concentration in the Yoshida nutrient solution still showed availability of this element. This availability after $7 \mathrm{~d}$ was $9.34,15.37$, and $22.84 \%$ of the initial concentration, when the sources were $\mathrm{KH}_{2} \mathrm{PO}_{4}$, nano- $\mathrm{KH}_{2} \mathrm{PO}_{4}$, and nano- $\mathrm{KH}_{2} \mathrm{PO}_{4}$ with the enzyme, respectively (Figure 1).

These results confirm that there were two conditions of $\mathrm{P}$ availability in the nutrient solutions after 7 days of incubation with the rice plants: deficiency and sufficiency. Moreover, we

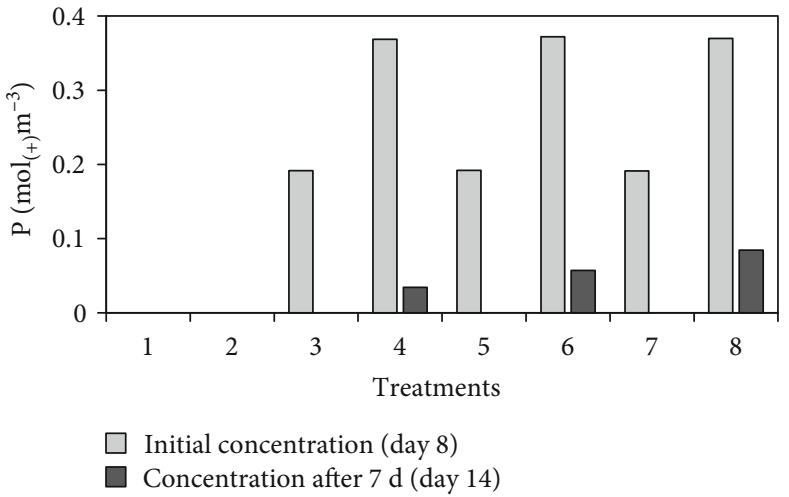

FIgURe 1: P concentration in the initial solution (day 8 from the beginning of the treatments) and its reduction after $7 \mathrm{~d}$ in the presence of rice plants (day 14 from the beginning of the treatments). Means of three independent replicates. Treatments: $1=$ distilled water; $2=$ type A gel $\left(0.1042 \mathrm{~g} \mathrm{~L}^{-1}\right) ; 3=50 \%[\mathrm{P}]_{\text {Yoshida }}$ solution from $\mathrm{KH}_{2} \mathrm{PO}_{4} ; 4=100 \%[\mathrm{P}]_{\text {Yoshida solution }}$ from $\mathrm{KH}_{2} \mathrm{PO}_{4}$; $5=50 \%$ de $[\mathrm{P}]_{\text {Yoshida }}$ solution from nano- $\mathrm{KH}_{2} \mathrm{PO}_{4} ; \quad 6=100 \%$ $[\mathrm{P}]_{\text {Yoshida solution }}$ from nano- $\mathrm{KH}_{2} \mathrm{PO}_{4} ; 7=50 \%[\mathrm{P}]_{\text {Yoshida solution }}$ from nano- $\mathrm{KH}_{2} \mathrm{PO}_{4}$ with trypsin $\left(0.1 \mathrm{mg} \mathrm{L}^{-1}\right) ; 8=100 \%[\mathrm{P}]_{\text {Yoshida }}$ solution from nano- $\mathrm{KH}_{2} \mathrm{PO}_{4}$ with trypsin $\left(0.2 \mathrm{mg} \mathrm{L}^{-1)}\right.$.

could observe differences regarding $\mathrm{P}$ uptake depending on the source of this element. Indeed, the nanofertilizer with the addition of trypsin exhibited the highest concentration in the nutrient solution after 7 days, as compared to the rest of the sources evaluated. Hence, $\mathrm{P}$ releasing dynamics of the absorbed form in nanofertilizers was much slower than that of the ionic forms. Phosphorus uptake efficiency is defined as the capacity of the roots to absorb $\mathrm{P}$ from the growth medium [22]. Under our experimental conditions, uptake efficiency of $\mathrm{KH}_{2} \mathrm{PO}_{4}$ was $90.6 \%$, that of nano- $\mathrm{KH}_{2} \mathrm{PO}_{4}$ was $84.63 \%$, and that of nano- $\mathrm{KH}_{2} \mathrm{PO}_{4}$ with trypsin was $77.16 \%$. Consequently, our findings could suggest a lower $\mathrm{P}$ uptake efficiency displayed by the nanofertilizers. However, plants treated with the nanofertilizer and the enzyme displayed normal development, demonstrating a greater $\mathrm{P}$ uptake efficiency when using the nanofertilizer. Due to their high surface area to volume ratio, nanofertilizers are more effective in promoting efficient nutrient uptake by crops (having more penetration capacity) than most conventional fertilizers of polymeric type $[23,24]$.

3.2. Plant Height. After $7 \mathrm{~d}$, plant height increased by 1.6 and $1.3 \%$ with distilled water and the polymer, respectively. When the $50 \% \mathrm{P}$ concentration was added, from $\mathrm{KH}_{2} \mathrm{PO}_{4}$, nano- $\mathrm{KH}_{2} \mathrm{PO}_{4}$, and nano- $\mathrm{KH}_{2} \mathrm{PO}_{4}$ with the enzyme, plant height increased by $2.85,2.73$, and $2.31 \%$, respectively. With the same sources used at $100 \% \mathrm{P}$ concentrations of the Yoshida solution, plant height was slightly greater, with increases of 2.61, 2.50, and 2.29\%, respectively (Figure 2).

The sampling done at 14 days of the treatment showed accumulated growth increases of 4.81 and $4.14 \%$ with distilled water and the polymer, respectively. The 50\% $\mathrm{P}$ concentrations supplied from $\mathrm{KH}_{2} \mathrm{PO}_{4}$, nano- $\mathrm{KH}_{2} \mathrm{PO}_{4}$, and nano- $\mathrm{KH}_{2} \mathrm{PO}_{4}$ with the enzyme caused height increases of $8.33,7.03$, and $6.28 \%$, respectively. Height increases when 


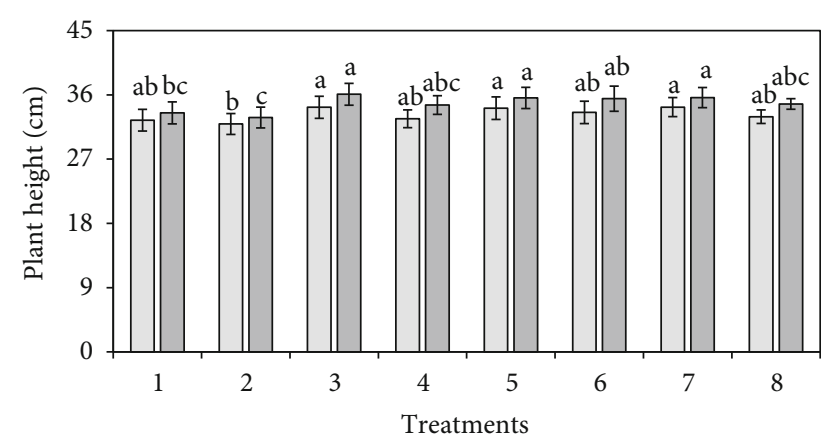

$\square 7 \mathrm{~d}$

$\square 14 \mathrm{~d}$

Figure 2: Height of rice plants cultivar Morelos A-2010 treated for 14 days with different sources and concentrations of P. Means \pm SD with different letters in each sampling date are statistically different (LSD, $P \leq 0.05 ; n=8)$. Treatments: $1=$ distilled water; $2=$ type A gel; $3=50 \%[\mathrm{P}]_{\text {Yoshida solution }}$ from $\mathrm{KH}_{2} \mathrm{PO}_{4} ; 4=100 \%[\mathrm{P}]_{\text {Yoshida solution }}$ from $\mathrm{KH}_{2} \mathrm{PO}_{4} ; 5=50 \%[\mathrm{P}]_{\text {Yoshida solution }}$ from nano- $\mathrm{KH}_{2} \mathrm{PO}_{4}$; $6=100 \%[\mathrm{P}]_{\text {Yoshida solution }}$ from nano- $\mathrm{KH}_{2} \mathrm{PO}_{4} ; 7=50 \%[\mathrm{P}]_{\text {Yoshida }}$ solution from nano- $\mathrm{KH}_{2} \mathrm{PO}_{4}$ with trypsin $\left(0.1 \mathrm{mg} \mathrm{L}^{-1}\right) ; 8=100 \%$ $[\mathrm{P}]_{\text {Yoshida solution }}$ from nano- $\mathrm{KH}_{2} \mathrm{PO}_{4}$ with trypsin $\left(0.2 \mathrm{mg} \mathrm{L}^{-1}\right)$.

supplying $100 \% \mathrm{P}$ in the Yoshida solution were slightly higher, independent of the source of $\mathrm{P}$, with increases of 8.66, 8.37, and $7.82 \%$ for $\mathrm{KH}_{2} \mathrm{PO}_{4}$, nano- $\mathrm{KH}_{2} \mathrm{PO}_{4}$, and nano- $\mathrm{KH}_{2} \mathrm{PO}_{4}$ with the enzyme, respectively, as compared to those observed in plants exposed to nutrient solutions with 50\% P (Figure 2).

Even though there are no significant differences in plant height between treatments with P (treatment 3 to 8 ) in both samplings, our results indicate that the percentage height increases were higher when $\mathrm{P}$ was supplied from $\mathrm{KH}_{2} \mathrm{PO}_{4}$ (Figure 2).

Under our experimental conditions, both $\mathrm{P}$ sources and their concentrations did not significantly affect plant height in rice. Contrasting with the results obtained herein, Liu and Lal [25] synthesized hydroxyapatite $\left(\mathrm{Ca}_{5}\left(\mathrm{PO}_{4}\right)_{3} \mathrm{OH}\right)$ nanoparticles (NPs), approximately $19 \mathrm{~nm}$ in size, and evaluated their effect on soybean (Glycine max) in a substrate $(50 \%$ perlite and $50 \%$ peat) in the greenhouse. The data showed that the application of nanoparticles increased the growth rate and seed yield by 33 and 20\%, respectively, compared against those of plants treated with regular phosphorus fertilizer $\left(\mathrm{Ca}\left(\mathrm{H}_{2} \mathrm{PO}_{4}\right)_{2}\right)$, demonstrating that soybean roots absorb hydroxyapatite nanoparticles as an efficient $\mathrm{P}$ source, maintaining healthy growth and high yield. Nevertheless, NPs may increase reactive oxygen species (ROS) levels in plants, which causes cytotoxic effects. The enhanced ROS levels triggered by NPs may lead to the activation of defense pathways to combat the oxidative stress. When plants achieve an efficient control of ROS, these molecules can be used as signals to regulate growth, development, and responses to environmental cues [26].

3.3. Number of Leaves. After 7 and $14 \mathrm{~d}$ from the beginning of the treatments, the increase in the number of leaves was affected by $\mathrm{P}$ concentration in the nutrient solutions, with a

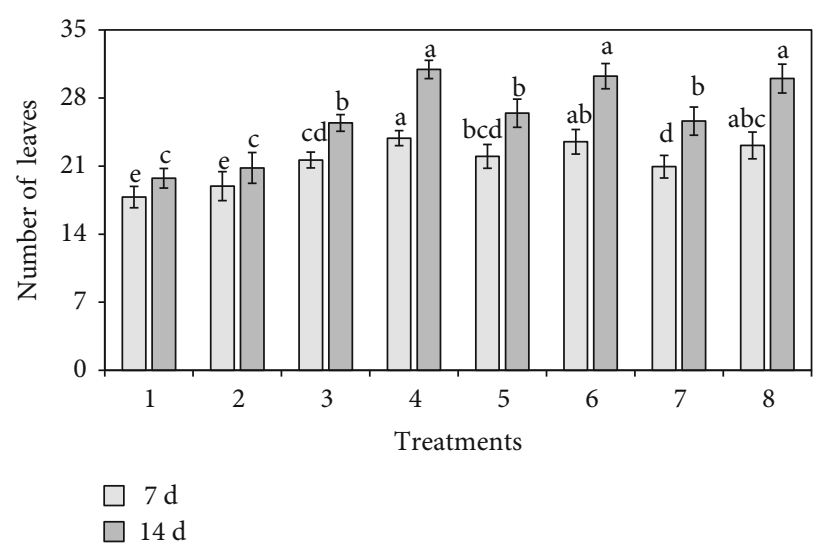

FIgURe 3: Number of leaves in rice plants cultivar Morelos A-2010 treated for 14 days with different sources and concentrations of $\mathrm{P}$. Means \pm SD with different letters in each sampling date are statistically different (LSD, $P \leq 0.05 ; n=8)$. Treatments: $1=$ distilled water; $2=$ type A gel; $3=50 \%[\mathrm{P}]_{\text {Yoshida solution }}$ from $\mathrm{KH}_{2} \mathrm{PO}_{4} ; 4=100 \%[\mathrm{P}]_{\text {Yoshida solution }}$ from $\mathrm{KH}_{2} \mathrm{PO}_{4} ; 5=50 \%$ $[\mathrm{P}]_{\text {Yoshida solution }}$ from nano- $\mathrm{KH}_{2} \mathrm{PO}_{4} ; 6=100 \%[\mathrm{P}]_{\text {Yoshida solution }}$ from nano- $\mathrm{KH}_{2} \mathrm{PO}_{4} ; 7=50 \%[\mathrm{P}]_{\text {Yoshida solution }}$ from nano- $\mathrm{KH}_{2} \mathrm{PO}_{4}$ with trypsin $\left(0.1 \mathrm{mg} \mathrm{L}^{-1}\right) ; 8=100 \%[\mathrm{P}]_{\text {Yoshida solution }}$ from nano$\mathrm{KH}_{2} \mathrm{PO}_{4}$ with trypsin $\left(0.2 \mathrm{mg} \mathrm{L}^{-1}\right)$.

positive relationship between the number of leaves and the $\mathrm{P}$ concentration (Figure 3 ).

Considering the measurements done at the beginning of the application of treatments and $7 \mathrm{~d}$ after the beginning of the treatments, plants treated with distilled water and the polymer had 2.0 and 2.3 more leaves, respectively. Treatments with $50 \% \mathrm{P}$ concentration from $\mathrm{KH}_{2} \mathrm{PO}_{4}$, nano$\mathrm{KH}_{2} \mathrm{PO}_{4}$, and nano- $\mathrm{KH}_{2} \mathrm{PO}_{4}$ with trypsin increased the number of leaves by $4.3,4.7$, and 4.0 leaves, respectively. Finally, treatments with $100 \% \mathrm{P}$ concentration from $\mathrm{KH}_{2} \mathrm{PO}_{4}$, nano- $\mathrm{KH}_{2} \mathrm{PO}_{4}$, and nano- $\mathrm{KH}_{2} \mathrm{PO}_{4}$ with trypsin showed 6.8, 6.6, and 6.8 more leaves (Figure 3).

Measurements carried out $14 \mathrm{~d}$ after treatment applications revealed that rice plants treated with distilled water and the polymer increased the number of leaves by 3.9 and 4.1, respectively, with respect to the beginning of the application. Treatments with $50 \% \mathrm{P}$ concentrations from $\mathrm{KH}_{2} \mathrm{PO}_{4}$, nano- $-\mathrm{KH}_{2} \mathrm{PO}_{4}$, and nano- $\mathrm{KH}_{2} \mathrm{PO}_{4}$ with the enzyme increased the number of leaves by 8.1, 9.1, and 8.7, respectively, compared to the number of leaves registered at the beginning of the treatment application. With the same $\mathrm{P}$ sources but at $100 \%$ concentrations, plants increased the number of leaves by $13.9,13.3$, and 13.7, respectively, compared to the measurements performed at the beginning of the treatments (Figure 3).

In other grass species like maize (Zea mays) and perennial ryegrass (Lolium perenne), $\mathrm{P}$ deficiency decreases cell division rate and cell expansion, but does not affect cell morphogenesis $[27,28]$. However, plants even belonging to the same genus can differ in their tolerance to P deficiency. This difference is mainly due to their capacity to maintain cell division, the expansion of epidermal cells of the leaves, or both [28]. In this research, the plants treated with $50 \% \mathrm{P}$ of the Yoshida solution underwent three weeks $(21 \mathrm{~d})$ of stress 


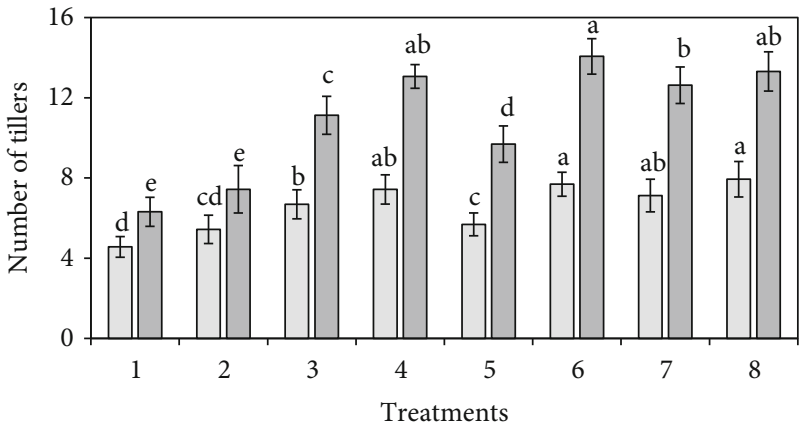

$\square 7 \mathrm{~d}$

$\square 14 \mathrm{~d}$

Figure 4: Number of tillers in rice plants cultivar Morelos A-2010 treated for 14 days with different sources and concentrations of $\mathrm{P}$. Means \pm SD with different letters in each sampling date are statistically different (LSD, $P \leq 0.05 ; n=8)$. Treatments: $1=$ distilled water; $2=$ type A gel; $3=50 \%[\mathrm{P}]_{\text {Yoshida solution }}$ from $\mathrm{KH}_{2} \mathrm{PO}_{4} ; 4=100 \%[\mathrm{P}]_{\text {Yoshida solution }}$ from $\mathrm{KH}_{2} \mathrm{PO}_{4} ; 5=50 \%$ $[\mathrm{P}]_{\text {Yoshida solution }}$ from nano- $\mathrm{KH}_{2} \mathrm{PO}_{4} ; 6=100 \%[\mathrm{P}]_{\text {Yoshida solution }}$ from nano- $\mathrm{KH}_{2} \mathrm{PO}_{4} ; 7=50 \%[\mathrm{P}]_{\text {Yoshida solution }}$ from nano- $\mathrm{KH}_{2} \mathrm{PO}_{4}$ with trypsin $\left(0.1 \mathrm{mg} \mathrm{L}^{-1}\right) ; 8=100 \%[\mathrm{P}]_{\text {Yoshida solution }}$ from nano$\mathrm{KH}_{2} \mathrm{PO}_{4}$ with trypsin $\left(0.2 \mathrm{mg} \mathrm{L}^{-1}\right)$.

condition from $\mathrm{P}$ deficiency, considering the $7 \mathrm{~d}$ when this element was not supplied, period previous to the beginning of treatment application. Thus, this fact may help explain the decrease in the number of leaves observed in the first sampling. Similarly, soybean seedlings deprived of $\mathrm{P}$ for $32 \mathrm{~d}$ showed decreasing rates of leaf initiation after 2 weeks, despite the apex being similar in size and number of cells to that of control plants [29].

In rice, symptoms of $\mathrm{P}$ deficiency include dark green color of plants with erect leaves and reduced number of tillers [30]. Moreover, P-deficient plants may exhibit thin shoots and delayed development, as well as decreased number of leaves, panicles, and seeds per panicle. Young leaves seem to be healthy, but older leaves turn brown and die. Red and purple color can develop on the leaves if the variety accumulates anthocyanins. Under our experimental conditions, reductions of $\mathrm{P}$ availability in the nutrient solution when $\mathrm{P}$ was supplied at $50 \%$ of the original strength (Figure 1) confirms P deficiency.

3.4. Number of Tillers. Treatments tested significantly affected the number of tillers (Figure 4).

After $7 \mathrm{~d}$ of beginning the treatments, number of tillers increased by 1.1 and 1.9 in plants treated with distilled water and the polymer, respectively. Plants exposed to the nutrient solution containing $50 \% \mathrm{P}$ of the original strength from $\mathrm{KH}_{2} \mathrm{PO}_{4}$, nano- $\mathrm{KH}_{2} \mathrm{PO}_{4}$, and nano- $\mathrm{KH}_{2} \mathrm{PO}_{4}$ with trypsin showed increases of 2.8,2.4, and 3.9 in the number of tillers, respectively. In the $100 \% \mathrm{P}$ concentration of the Yoshida solution supplied from the sources mentioned before, the increases in the number of tillers were $3.9,4.1$, and 4.2 , respectively, as compared to the number of tillers showed at the beginning of the experiment (Figure 4).

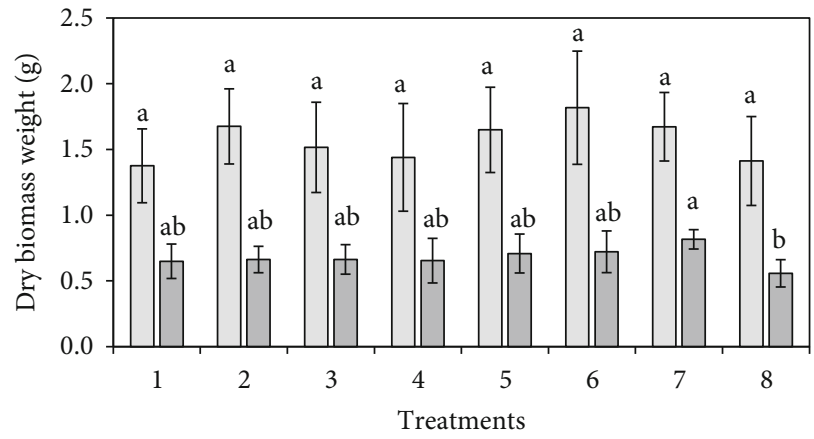

$\square$ Shoot

$\square$ Root

FIgURE 5: Dry biomass weight of shoots and roots of rice plants cultivar Morelos A-2010 treated for 14 days with different sources and concentrations of $\mathrm{P}$. Means $\pm \mathrm{SD}$ with different letters in each organ are statistically different (LSD, $P \leq 0.05 ; n=8)$. Treatments: $1=$ distilled water; $2=$ type A gel; $3=50 \%[\mathrm{P}]_{\text {Yoshida solution }}$ from $\mathrm{KH}_{2} \mathrm{PO}_{4} ; 4=100 \%[\mathrm{P}]_{\text {Yoshida solution }}$ from $\mathrm{KH}_{2} \mathrm{PO}_{4} ; 5=50 \%$ $[\mathrm{P}]_{\text {Yoshida solution }}$ from nano- $\mathrm{KH}_{2} \mathrm{PO}_{4} ; 6=100 \%[\mathrm{P}]_{\text {Yoshida solution }}$ from nano- $\mathrm{KH}_{2} \mathrm{PO}_{4} ; 7=50 \%[\mathrm{P}]_{\text {Yoshida solution }}$ from nano- $\mathrm{KH}_{2} \mathrm{PO}_{4}$ with trypsin $\left(0.1 \mathrm{mg} \mathrm{L}^{-1}\right) ; 8=100 \%$ [P]Yoshida solution from nano- $\mathrm{KH}_{2} \mathrm{PO}_{4}$ with trypsin $\left(0.2 \mathrm{mg} \mathrm{L}^{-1}\right)$.

At $14 \mathrm{~d}$, in plants treated with distilled water and the polymer, the number of tillers increased by 2.8 and 3.9, respectively. The application of $50 \% \mathrm{P}$ concentrations of the Yoshida solution from $\mathrm{KH}_{2} \mathrm{PO}_{4}$, nano- $\mathrm{KH}_{2} \mathrm{PO}_{4}$, and nano$\mathrm{KH}_{2} \mathrm{PO}_{4}$ with trypsin increased the number of tillers by 7.2 , 6.4, and 9.4, respectively. Finally, plants exposed to $100 \% \mathrm{P}$ concentration with the same sources increased the number of tillers by 7.2, 10.5, and 9.6, respectively. In the case of the plants treated with nano- $\mathrm{KH}_{2} \mathrm{PO}_{4}$, there is an important increase in the number of tillers only when going from 50 to $100 \% \mathrm{P}$ concentration in the medium (Figure 4).

There is a positive relationship between the number of tillers and the initial $\mathrm{P}$ concentration in the nutrient solutions (Figure 4). P is particularly important in early growth stages. It is mobile within the plant and promotes the development of roots, tiller creation, early flowering, and maturation (especially at lower temperatures). Plants remobilize $\mathrm{P}$ within their tissues during advanced growth stages if this element has been absorbed in enough quantities during early growth stages [30]. A good P supply induces grater tiller generation in rice plants [31].

3.5. Dry Biomass. Shoots dry biomass weight showed no significant differences among plants treated with distilled water, polymer, and $\mathrm{P}$ (Figure 5).

The treatment period in rice plants was short $(14 \mathrm{~d})$, which might have caused the absence of significant differences between treatments. In rice, the overexpression of the high-affinity phosphate transporter OsPT6 enhanced growth, biomass production, and $\mathrm{P}$ accumulation in various tissues, while grain yield per transgenic plant was much higher than that of the wild-type plants under field conditions [32]. Coincidently, the constitutive expression of these gene in soybean improved growth under conditions of low 
P supply in hydroponics [33]. Since high-affinity phosphate transporters are transcriptionally induced by phosphate starvation, the gene OsPT6 and other members of this family could be induced under our experimental conditions, so that shoot dry biomass weight was increased.

Regarding the dry mass of the roots, the highest mean $(0.98164 \mathrm{~g})$ was observed in the plants treated with nano$\mathrm{KH}_{2} \mathrm{PO}_{4}$ at $50 \%$ of the $\mathrm{P}$ concentration of the Yoshida solution plus the enzyme trypsin. Plants treated with nano$\mathrm{KH}_{2} \mathrm{PO}_{4}$ at $100 \% \mathrm{P}$ concentration with the enzyme showed the lowest mean $(0.5579 \mathrm{~g}$ ) (Figure 5$)$. Although no significant differences in root dry biomass weight were observed among the rest of the treatments, it is important to note that the treatment with $100 \% \mathrm{P}$ concentration of the Yoshida solution from nano- $\mathrm{KH}_{2} \mathrm{PO}_{4}$ with the enzyme (treatment 8) had a lower dry biomass of the roots than did the rest of the treatments. Indeed, root dry biomass weight in this treatment represented only $85 \%$ of that observed in treatments 1 and 2 (controls with no $\mathrm{P}$ added).

In Nipponbare rice plants exposed to P deficiency, a significant decrease in shoot growth in benefit of the root system was observed [34]. The decrease in shoot growth was associated with a decrease in the elongation rate of the leaves, while the final leaf size remained unchanged. Therefore, the treatment with nano- $\mathrm{KH}_{2} \mathrm{PO}_{4}$ at $100 \% \mathrm{P}$ concentration with the enzyme induced smaller morphological changes in the roots because of sufficient P supply [35].

Total dry biomass and dry shoot/root biomass ratio were not significantly affected by the treatments tested. Nonetheless, we could observe that the plants exposed to treatment $8\left(100 \% \mathrm{P}\right.$ concentration from nano- $\mathrm{KH}_{2} \mathrm{PO}_{4}$ with the enzyme) showed the lowest total dry biomass (Table 2). The differences in essential macronutrients like $\mathrm{P}$ produce an accumulation of carbohydrates in leaves and roots and modify the dry biomass ratio between shoots and roots [36]. Thus, the lower total dry biomass weight observed in plants exposed to treatment 8 could be due to a lower accumulation of carbohydrates, an indicator of $\mathrm{P}$ sufficiency status. On the other hand, the short study period could be another factor influencing shoot and root biomass weight observed.

3.6. Concentration of Phosphorus in Shoots. The highest $\mathrm{P}$ concentration was found in the treatments with $100 \% \mathrm{P}$ of the Yoshida solution, independent of the source used: $\mathrm{KH}_{2} \mathrm{PO}_{4}, 4.9141 \mathrm{~g} \mathrm{~kg}^{-1}$; nano- $\mathrm{KH}_{2} \mathrm{PO}_{4}, 4.4617 \mathrm{~g} \mathrm{~kg}^{-1}$; and nano- $\mathrm{KH}_{2} \mathrm{PO}_{4}$ with the enzyme, $4.6362 \mathrm{~g} \mathrm{~kg}^{-1} \mathrm{P}$ in shoots. On the other hand, lower $\mathrm{P}$ concentrations were found in the treatments with $50 \% \quad \mathrm{P}$ supplied from $\mathrm{KH}_{2} \mathrm{PO}_{4}$ $\left(3.6691 \mathrm{~g} \mathrm{~kg}^{-1}\right)$, nano- $\mathrm{KH}_{2} \mathrm{PO}_{4}\left(3.4891 \mathrm{~g} \mathrm{~kg}^{-1}\right)$, and nano$\mathrm{KH}_{2} \mathrm{PO}_{4}$ with the enzyme $\left(3.5871 \mathrm{~g} \mathrm{~kg}^{-1}\right)$. The lowest $\mathrm{P}$ concentrations were found in the control treatments with distilled water $\left(1.3405 \mathrm{~g} \mathrm{~kg}^{-1}\right)$ and the polymer $\left(1.2757 \mathrm{~g} \mathrm{~kg}^{-1}\right)$ (Figure 6).

The $\mathrm{P}$ concentration observed in shoots (Figure 6) in the treatments with $100 \% \mathrm{P}$ in the Yoshida solution is positively associated with the reduction of $\mathrm{P}$ in the solution (Figure 1). Consequently, there is a higher $\mathrm{P}$ concentration in shoots
TABLE 2: Total dry biomass and dry shoot/root biomass ratio of rice plants cultivar Morelos A-2010 treated for $14 \mathrm{~d}$ with different sources and concentrations of $\mathrm{P}$.

\begin{tabular}{lcc}
\hline Treatment & Total dry biomass $(g)$ & Dry shoot/root biomass ratio \\
\hline 1 & $2.025 \pm 0.321^{\mathrm{a}}$ & $2.293 \pm 0.416^{\mathrm{a}}$ \\
2 & $2.338 \pm 0.378^{\mathrm{a}}$ & $2.521 \pm 0.193^{\mathrm{a}}$ \\
3 & $2.179 \pm 0.453^{\mathrm{a}}$ & $2.178 \pm 0.253^{\mathrm{a}}$ \\
4 & $2.094 \pm 0.434^{\mathrm{a}}$ & $2.623 \pm 0.816^{\mathrm{a}}$ \\
5 & $2.358 \pm 0.471^{\mathrm{a}}$ & $2.351 \pm 0.098^{\mathrm{a}}$ \\
6 & $2.539 \pm 0.586^{\mathrm{a}}$ & $2.483 \pm 0.135^{\mathrm{a}}$ \\
7 & $2.489 \pm 0.279^{\mathrm{a}}$ & $2.090 \pm 0.335^{\mathrm{a}}$ \\
8 & $1.970 \pm 0.441^{\mathrm{a}}$ & $2.474 \pm 0.124^{\mathrm{a}}$ \\
\hline
\end{tabular}

Means \pm SD with different letters in each column are statistically different (LSD, $P \leq 0.05 ; n=8)$. Treatments: $1=$ distilled water; $2=$ type A gel; $3=50 \%[\mathrm{P}]_{\text {Yoshida solution }}$ from $\mathrm{KH}_{2} \mathrm{PO}_{4} ; 4=100 \%[\mathrm{P}]_{\text {Yoshida solution }}$ from $\mathrm{KH}_{2} \mathrm{PO}_{4} ; 5=50 \%[\mathrm{P}]_{\text {Yoshida solution }}$ from nano- $\mathrm{KH}_{2} \mathrm{PO}_{4} ; 6=100 \%[\mathrm{P}]_{\text {Yoshida }}$ solution from nano- $\mathrm{KH}_{2} \mathrm{PO}_{4} ; 7=50 \%[\mathrm{P}]_{\text {Yoshida solution }}$ from nano- $\mathrm{KH}_{2} \mathrm{PO}_{4}$ with trypsin $\left(0.1 \mathrm{mg} \mathrm{L}^{-1}\right) ; 8=100 \%[\mathrm{P}]_{\text {Yoshida solution }}$ from nano- $\mathrm{KH}_{2} \mathrm{PO}_{4}$ with trypsin $\left(0.2 \mathrm{~m} \mathrm{~L}^{-1}\right)$.

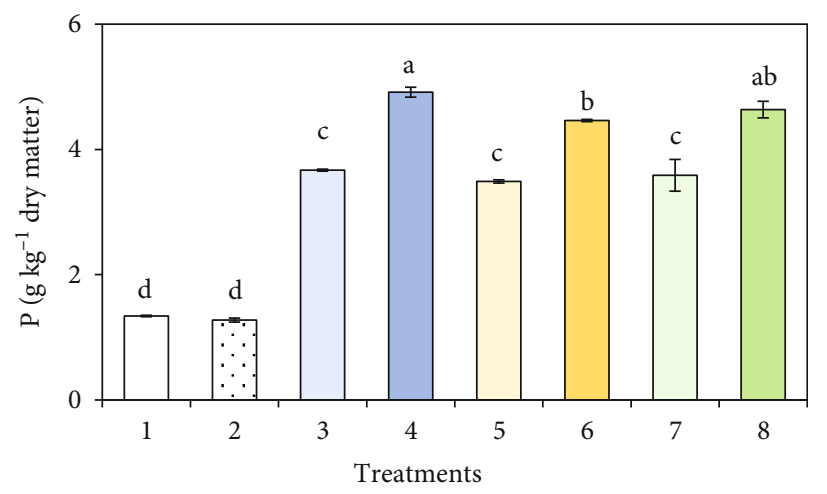

FIGURE 6: Phosphorus concentration in shoots of rice plants cultivar Morelos A-2010 treated for $14 \mathrm{~d}$ with different sources and concentrations of P. Means \pm SD with different letters are statistically different (LSD, $P \leq 0.05 ; n=4)$. Treatments: $1=$ distilled water; $2=$ type A gel; $3=50 \%[\mathrm{P}]_{\text {Yoshida solution }}$ from $\mathrm{KH}_{2} \mathrm{PO}_{4} ; 4=100 \%[\mathrm{P}]_{\text {Yoshida solution }}$ from $\mathrm{KH}_{2} \mathrm{PO}_{4} ; 5=50 \%$ $[\mathrm{P}]_{\text {Yoshida solution }}$ from nano- $\mathrm{KH}_{2} \mathrm{PO}_{4} ; 6=100 \%[\mathrm{P}]_{\text {Yoshida solution }}$ from nano- $\mathrm{KH}_{2} \mathrm{PO}_{4} ; 7=50 \%[\mathrm{P}]_{\text {Yoshida solution }}$ from nano- $\mathrm{KH}_{2} \mathrm{PO}_{4}$ with trypsin $\left(0.1 \mathrm{mgL}^{-1}\right) ; 8=100 \%[\mathrm{P}]_{\text {Yoshida }}$ solution from nano$\mathrm{KH}_{2} \mathrm{PO}_{4}$ with trypsin $\left(0.2 \mathrm{mg} \mathrm{L}^{-1}\right)$.

when the reduction of $\mathrm{P}$ in the solution is greater; in this case, the solution where $\mathrm{P}$ was supplied from $\mathrm{KH}_{2} \mathrm{PO}_{4}$ (Figure 6).

Most reports regarding the application of nanoparticles in plants has been carried out with metallic and metallic oxide nanoparticles, such as $\mathrm{TiO}_{2}, \mathrm{Ag}^{0}, \mathrm{CuO}, \mathrm{CeO}_{2}, \mathrm{FexO}$, and $\mathrm{ZnO}$ [37]. To the best of our knowledge, our study demonstrates for the first time that $\mathrm{P}$ nanoparticles are indeed absorbed and transported in rice, which has been evidenced by the increased concentrations of $\mathrm{P}$ found in shoot tissues (Figure 6). In maize, absorption, translocation, and distribution of $\mathrm{CuO}(\mathrm{nCuO})$ nanoparticles $(20-40 \mathrm{~nm})$ in roots, transport through the xylem, and their return to the roots through the phloem have been experimentally proved [38]. 


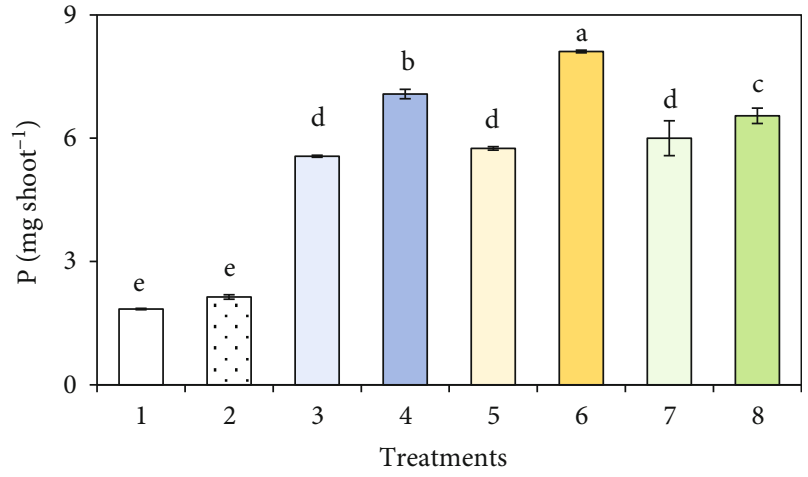

Figure 7: Phosphorus accumulation in shoots of rice plants cultivar Morelos A-2010 treated for $14 \mathrm{~d}$ with different sources and concentrations of $\mathrm{P}$. Means $\pm \mathrm{SD}$ with different letters are statistically different (LSD, $P \leq 0.05 ; n=4)$. Treatments: $1=$ distilled water; $2=$ type A gel; $3=50 \%[\mathrm{P}]_{\text {Yoshida solution }}$ from $\mathrm{KH}_{2} \mathrm{PO}_{4} ; 4=100 \%[\mathrm{P}]_{\text {Yoshida solution }}$ from $\mathrm{KH}_{2} \mathrm{PO}_{4} ; 5=50 \%$ $[\mathrm{P}]_{\text {Yoshida solution }}$ from nano- $\mathrm{KH}_{2} \mathrm{PO}_{4} ; 6=100 \%[\mathrm{P}]_{\text {Yoshida solution }}$ from nano- $\mathrm{KH}_{2} \mathrm{PO}_{4} ; 7=50 \%[\mathrm{P}]_{\text {Yoshida solution }}$ from nano- $\mathrm{KH}_{2} \mathrm{PO}_{4}$ with trypsin $\left(0.1 \mathrm{mg} \mathrm{L}^{-1}\right) ; 8=100 \%[\mathrm{P}]_{\text {Yoshida solution }}$ from nano$\mathrm{KH}_{2} \mathrm{PO}_{4}$ with trypsin $\left(0.2 \mathrm{mg} \mathrm{L}^{-1}\right)$.

3.7. Accumulation of Phosphorus in Shoots. The application of nano- $\mathrm{KH}_{2} \mathrm{PO}_{4} 100 \% \mathrm{P}$ concentration in the Yoshida solution resulted in higher $\mathrm{P}$ contents $(8.1114 \mathrm{mg})$. Interestingly, $\mathrm{P}$ contents were the highest in plants exposed to treatment 6, as compared to the rest of the treatments tested (Figure 7).

The decrease of $\mathrm{P}$ in the solution (Figure 1) may suggest a lower $\mathrm{P}$ uptake rate from the medium when this element was supplied from nanofertilizers (lower P uptake efficiency). However, results showing $\mathrm{P}$ accumulation demonstrated a higher physiological efficiency when this element was supplied as nano- $\mathrm{KH}_{2} \mathrm{PO}_{4}$ than when it was supplied from $\mathrm{KH}_{2} \mathrm{PO}_{4}$ and nano- $\mathrm{KH}_{2} \mathrm{PO}_{4}$ with trypsin (Figure 7). The physiological efficiency of shoots links the difference between the dry biomass weights of the shoots of the treatment with $\mathrm{P}$ and the control (treatment 1 ) with the difference in $\mathrm{P}$ content in the shoots of the treatment with $\mathrm{P}$ and the control (treatment 1). Similar response to foliar phosphorus application in bean plants (Phaseolus vulgaris) under drought has been reported [39].

We also observed significant differences in $\mathrm{P}$ accumulation between treatments where it was supplied at 100\% concentration of the Yoshida solution. These differences are specifically observed among treatments 4,6 , and 8 (Figure 7). In this case, the differences found resulted from the sources of $\mathrm{P}$ used, being the treatment with nano$\mathrm{KH}_{2} \mathrm{PO}_{4}$ which had the highest $\mathrm{P}$ accumulation $(8.1114 \mathrm{mg}$ ), followed by the treatments with $\mathrm{KH}_{2} \mathrm{PO}_{4}$ and nano$\mathrm{KH}_{2} \mathrm{PO}_{4}$ with the enzyme $(7.0763$ and $6.5463 \mathrm{mg}$, respectively).

3.8. Concentrations of Phosphorus in Roots. Plants exposed to the controls, distilled water (1) and the polymer (2), showed the lowest concentrations of $\mathrm{P}$, with values of 0.94124 and $1.02275 \mathrm{~g} \mathrm{~kg}^{-1}$, respectively. When $\mathrm{P}$ was supplied at $50 \%$ of the concentration indicated in the Yoshida solution, there

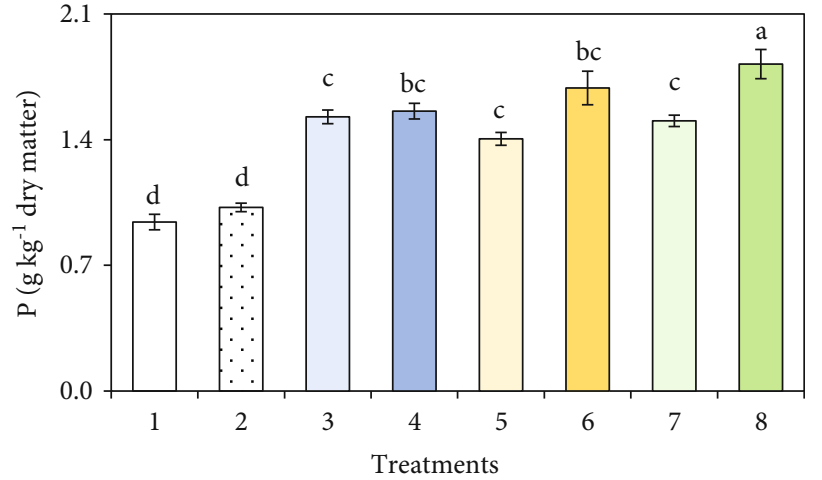

FIGURE 8: Phosphorus concentration in roots of rice plants cultivar Morelos A-2010 treated for $14 \mathrm{~d}$ with different sources and concentrations of $\mathrm{P}$. Means $\pm \mathrm{SD}$ with different letters in each figure are statistically different (LSD, $P \leq 0.05 ; n=4)$. Treatments: $1=$ distilled water; $2=$ type A gel; $3=50 \%[\mathrm{P}]_{\text {Yoshida solution }}$ from $\mathrm{KH}_{2} \mathrm{PO}_{4} ; 4=100 \%[\mathrm{P}]_{\text {Yoshida solution }}$ from $\mathrm{KH}_{2} \mathrm{PO}_{4} ; 5=50 \%$ $[\mathrm{P}]_{\text {Yoshida solution }}$ from nano- $\mathrm{KH}_{2} \mathrm{PO}_{4} ; 6=100 \%[\mathrm{P}]_{\text {Yoshida solution }}$ from nano- $\mathrm{KH}_{2} \mathrm{PO}_{4} ; 7=50 \%[\mathrm{P}]_{\text {Yoshida solution }}$ from nano- $\mathrm{KH}_{2} \mathrm{PO}_{4}$ with trypsin $\left(0.1 \mathrm{mg} \mathrm{L}^{-1}\right) ; 8=100 \%[\mathrm{P}]_{\text {Yoshida solution }}$ from nano$\mathrm{KH}_{2} \mathrm{PO}_{4}$ with trypsin $\left(0.2 \mathrm{mg} \mathrm{L}^{-1}\right)$.

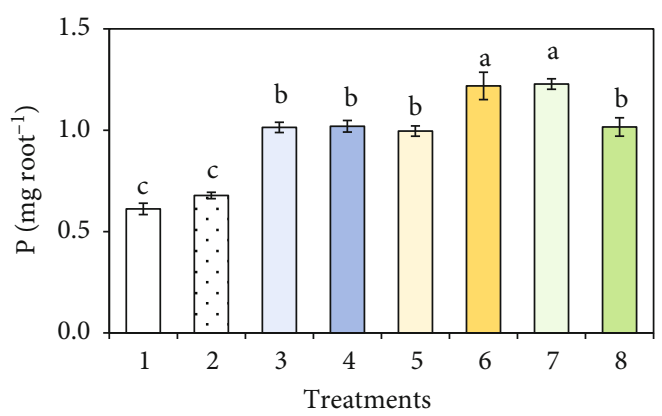

Figure 9: Phosphorus accumulation in roots of rice plants cultivar Morelos A-2010 treated for $14 \mathrm{~d}$ with different sources and concentrations of $\mathrm{P}$. Means $\pm \mathrm{SD}$ with different letters are statistically different (LSD, $P \leq 0.05 ; n=4)$. Treatments: $1=$ distilled water; $2=$ type A gel; $3=50 \%[\mathrm{P}]_{\text {Yoshida solution }}$ from $\mathrm{KH}_{2} \mathrm{PO}_{4} ; 4=100 \%[\mathrm{P}]_{\text {Yoshida solution }}$ from $\mathrm{KH}_{2} \mathrm{PO}_{4} ; 5=50 \%$ $[\mathrm{P}]_{\text {Yoshida solution }}$ from nano- $\mathrm{KH}_{2} \mathrm{PO}_{4} ; 6=100 \%[\mathrm{P}]_{\text {Yoshida solution }}$ from nano- $\mathrm{KH}_{2} \mathrm{PO}_{4} ; 7=50 \%[\mathrm{P}]_{\text {Yoshida solution }}$ from nano- $\mathrm{KH}_{2} \mathrm{PO}_{4}$ with trypsin $\left(0.1 \mathrm{mg} \mathrm{L}^{-1}\right) ; 8=100 \%[\mathrm{P}]_{\text {Yoshida solution }}$ from nano$\mathrm{KH}_{2} \mathrm{PO}_{4}$ with trypsin $\left(0.2 \mathrm{mg} \mathrm{L}^{-1}\right)$.

were no significant differences among the sources of $\mathrm{P}$ used. Conversely, when the $\mathrm{P}$ concentration was increased to $100 \%$, the use of nano- $\mathrm{KH}_{2} \mathrm{PO}_{4}$ with trypsin significantly increased $\mathrm{P}$ concentration in roots, as compared to the treatment with $\mathrm{KH}_{2} \mathrm{PO}_{4}$ and nano- $\mathrm{KH}_{2} \mathrm{PO}_{4}$ (Figure 8).

3.9. Accumulation of Phosphorus in Roots. The highest $\mathrm{P}$ accumulation values in roots were obtained in treatments 3 to 8 , all of which contained P. Nevertheless, it is important to point out that only in the treatments where this element was supplied from nano- $\mathrm{KH}_{2} \mathrm{PO}_{4}$ at 50 and $100 \% \mathrm{P}$ with no enzymes (treatments 5 and 6 ) was there a positive 
relationship between the $\mathrm{P}$ supplied and its accumulation in roots (Figure 9).

The uptake and transport of nanoparticles in plants are greatly important processes for the evaluation and application of nanotechnology in agriculture. The absorption of nanoparticles by plants is a very recent study field [40]. Importantly, there are various possible pathways leading to the absorption of nanoparticles by plant cells [2]. Thus, nanoparticles can enter the plant by interacting with transport proteins, aquaporins, or ionic channels, by creating new pores or by endocytosis.

Our results demonstrated a higher $\mathrm{P}$ uptake from the traditional sources (Figure 1). Moreover, differential activity of phosphate transporters may also influence $\mathrm{P}$ uptake and transport within plant tissues once absorbed. In rice, 13 genes of the Pht1 family have been isolated so far; eight of these have been functionally characterized. Among these characterized genes are OsOT1, OsPT6, OsPT9, and OsPT10, which are highly expressed in the roots and are therefore responsible for $\mathrm{P}$ absorption in rice. The OsOT1 gene is expressed constitutively in rice, indicating that this gene has an important function in phosphate uptake under various conditions of P supply. On the other hand, the genes OsPT6, OsPT9, and OsPT10 are expressed considerably under P deficiency and thus function under low or deficient conditions of this element [41].

In our study, treatment $8(100 \% \mathrm{P}$ of the Yoshida solution from nano- $\mathrm{KH}_{2} \mathrm{PO}_{4}$ with trypsin) resulted in the lowest dry root biomass weight, and therefore lowest root growth (Figure 5), and both features are associated with P sufficiency [42]. But this treatment does not provide the highest $\mathrm{P}$ accumulation in shoots (Figure 7) nor in roots (Figure 9). Instead, the highest mean values for these variables were achieved with treatment $6(100 \% \mathrm{P}$ in the Yoshida solution from nano- $\mathrm{KH}_{2} \mathrm{PO}_{4}$ ). These data suggest that the high initial availability of $\mathrm{P}$, achieved by the addition of the enzyme trypsin in treatment 8 , inhibited the expression of the genes that codify for high-affinity transporters, leaving active only the constitutive transporter OsOT1. Contrarily, in treatment 6, where $\mathrm{P}$ release is not immediate, a more efficient $\mathrm{P}$ absorption was induced, possibly via high-affinity transporters, which finally lead to a higher physiological efficiency both in shoots and in roots in this treatment. Moreover, in the absence or low availability of $\mathrm{P}$, genes of high-affinity transporters like OsPT6, OsPT9, and OsPT10 may have been expressed in roots. In a comparative study on seven rice genotypes, a high expression of the OsPT6 gene was reported in the IR66 variety under P deficiency, and this variety also showed a strong increase in root growth induced by P deficiency [43]. This coincides with the results here observed.

One of the great technical challenges to be overcome in the future is the fact that protocols to quantify nanoparticles within plant tissues are not well established yet. Furthermore, nanoparticle absorption, translocation, and accumulation processes depend on plant species, as well as size, type, chemical composition, functionalization, and stability of the nanoparticles [40].

In squash plants (Cucurbita maxima), $\mathrm{Fe}_{3} \mathrm{O}_{4}$ nanoparticles are absorbed by the roots and translocated through

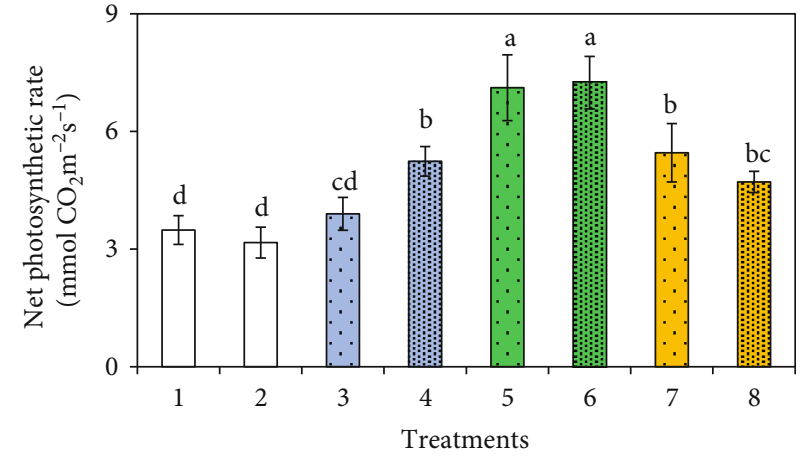

Figure 10: Photosynthetic rate of rice plants cultivar Morelos A2010 treated for $13 \mathrm{~d}$ with different sources and concentrations of P. Means \pm SD with different letters are statistically different (LSD, $P \leq 0.05 ; n=9)$. Treatments: $1=$ distilled water; $2=$ type A gel; $3=50 \%[\mathrm{P}]_{\text {Yoshida solution }}$ from $\mathrm{KH}_{2} \mathrm{PO}_{4} ; 4=100 \%[\mathrm{P}]_{\text {Yoshida solution }}$ from $\mathrm{KH}_{2} \mathrm{PO}_{4} ; 5=50 \%[\mathrm{P}]_{\text {Yoshida solution }}$ from nano- $\mathrm{KH}_{2} \mathrm{PO}_{4}$; $6=100 \%[\mathrm{P}]_{\text {Yoshida solution }}$ from nano- $\mathrm{KH}_{2} \mathrm{PO}_{4} ; 7=50 \%[\mathrm{P}]_{\text {Yoshida }}$ solution from nano- $\mathrm{KH}_{2} \mathrm{PO}_{4}$ with trypsin $\left(0.1 \mathrm{mg} \mathrm{L}^{-1}\right) ; 8=100 \%$ $[\mathrm{P}]_{\text {Yoshida solution }}$ from nano- $\mathrm{KH}_{2} \mathrm{PO}_{4}$ with trypsin $\left(0.2 \mathrm{mg} \mathrm{L}^{-1}\right)$.

the plant tissues; $45.5 \%$ of the absorbed nanoparticles was accumulated in the roots and $0.6 \%$ of the nanoparticles was detected in the leaves. Contrarily, in lima bean (Phaseolus limensis), there was no uptake or transport of the same nanoparticles, which evidences that the observed results can be highly influenced by the genotype of plant under evaluation [44].

3.10. Photosynthesis-Related Variables. The lowest $\mathrm{CO}_{2}$ fixation values were registered in the plants of treatments 1,2 , and 3 (distilled water, the polymer, and 50\% $\mathrm{P}$ of the Yoshida solution from $\mathrm{KH}_{2} \mathrm{PO}_{4}$, respectively), with values of 3.4858, 3.1664, and $3.8993 \mu \mathrm{mol} \mathrm{CO} \mathrm{m}^{-2} \mathrm{~s}^{-1}$, respectively. Contrarily, the highest photosynthetic rate values were observed in plants exposed to treatments 5 and 6 (50 and 100\% P concentration of the Yoshida solution supplied from nano$\mathrm{KH}_{2} \mathrm{PO}_{4}$ ), with mean values of 7.1149 and $7.2434 \mu \mathrm{mol}$ $\mathrm{CO}_{2} \mathrm{~m}^{-2} \mathrm{~s}^{-1}$, respectively (Figure 10), which represent more than double the photosynthetic rate registered in the control treatments and the treatment with the low P dose (50\% P of the Yoshida solution) from the conventional source.

Photosynthesis is a vital physiological process in plants and determines productivity. Photosynthetic activity greatly depends on P containing compound, and therefore, the efficient use of $\mathrm{P}$ in photosynthesis is a potentially important factor [45]. Phosphorus is a structural component of vital biomolecules, including amino acids, nucleic acids, energy source molecules (ATP, ADP, and PPi), phospholipids, and phytic acid, as well as participating in the photosynthetic activity [10]. Total P concentration in higher plants grown in high P supply conditions is over $5 \mathrm{~g} \mathrm{~kg}^{-1}$ dry matter, while under optimum $\mathrm{P}$ conditions, most crops show $\mathrm{P}$ concentrations under $4 \mathrm{~g} \mathrm{~kg}^{-1}$ dry matter [45]. In rice, the critical lowest value for $\mathrm{P}$ is $3 \mathrm{~g} \mathrm{~kg}^{-1}$ dry matter [46].

When associating the photosynthetic rate observed in our study (Figure 10) with those obtained for P concentration 
in shoots (Figure 6), we observe a direct relationship between them. In the control treatments ( 1 and 2, with no P), we obtained $\mathrm{P}$ concentrations under $2 \mathrm{~g} \mathrm{~kg}^{-1}$ dry matter. Moreover, they showed the lowest carbon fixation. In the treatments with $\mathrm{P}$ supply (3 to 8 ), the $\mathrm{P}$ concentrations in shoots were over $3 \mathrm{~g} \mathrm{~kg}^{-1}$ dry matter, the lowest critical value for rice. Consequently, the photosynthetic rate increased in these treatments (Figure 10). Additionally, the highest carbon fixation was registered in plants exposed to treatment 6 , which also showed the highest $\mathrm{P}$ accumulation in both shoots (Figure 7) and roots (Figure 9).

Photosynthetic rate of the plants treated with nano$\mathrm{KH}_{2} \mathrm{PO}_{4}$ in both $\mathrm{P}$ concentrations of the Yoshida solution showed a more efficient use of $\mathrm{P}$ in photosynthesis. Particularly, the photosynthetic efficiency in the use of $\mathrm{P}$ defines the relationship existing between the photosynthetic rate and leaf P concentration [45]. As compared to conventional fertilizers, nanofertilizers have a higher surface area due to a lower particle size which provides more sites to enable different metabolic processes in the plant system [23].

Stomatal conductance, intercellular $\mathrm{CO}_{2}$ concentration, and transpiration (Figures 11(a)-11(c)) maintain an inverse relationship with the photosynthetic rate (Figure 10).

The statistical differences shown in stomatal conductance, intercellular $\mathrm{CO}_{2}$ concentration, and transpiration are not related to the P status in shoots. Some studies suggest that under $\mathrm{P}$ deficiency, plants have a low photosynthetic rate due to the reduced stomatal conductance and the low $\mathrm{CO}_{2}$ concentrations in the substomatal cavity [47]. Particularly in two rice genotypes (Zhenongda 454, P-deficiency tolerant genotype and Sanyang'ai, Pdeficiency sensitive genotype), $\mathrm{P}$ deficiency decreased stomatal conductance but had no influence on the internal $\mathrm{CO}_{2}$ concentration. Therefore, the decrease in the photosynthetic rate observed in P-deficient plants is not due to stomatal limitation [48]. In addition, low P concentrations evaluated in four rice varieties (Akhanphou, MTU1010, RP BIO 226, and Swarna) decreased the photosynthetic rate, stomatal conductance, the transpiration rate, and the internal $\mathrm{CO}_{2}$ concentration in all varieties [49]. Under our experimental conditions, contrastingly, the absence or low level of P did not drastically affect stomatal conductance, intercellular $\mathrm{CO}_{2}$ concentration, or transpiration (Figure 11).

The relationship between the photosynthetic rate and the transpiration rate is an indicator used to characterize the instant water use efficiency (IWUE) [50]. When considering this indicator, plants under treatments with nano- $\mathrm{KH}_{2} \mathrm{PO}_{4}$ both at 50 and $100 \% \mathrm{P}$ of the Yoshida solution, would have a greater instant water use efficiency compared against plants treated with conventional phosphate fertilization and nano$\mathrm{KH}_{2} \mathrm{PO}_{4}$ with trypsin.

Several nanomaterials have been reported to improve growth, enhancing an efficient nutrient use. The high surface area and penetrability of nanomaterials make them potentially more efficient products in terms of nutrient use as compared to conventional fertilizers [4]. When considering phosphorus nanofertilizers, solubility and dispersion of insoluble forms, as well as absorption, fixation, and bioavail-
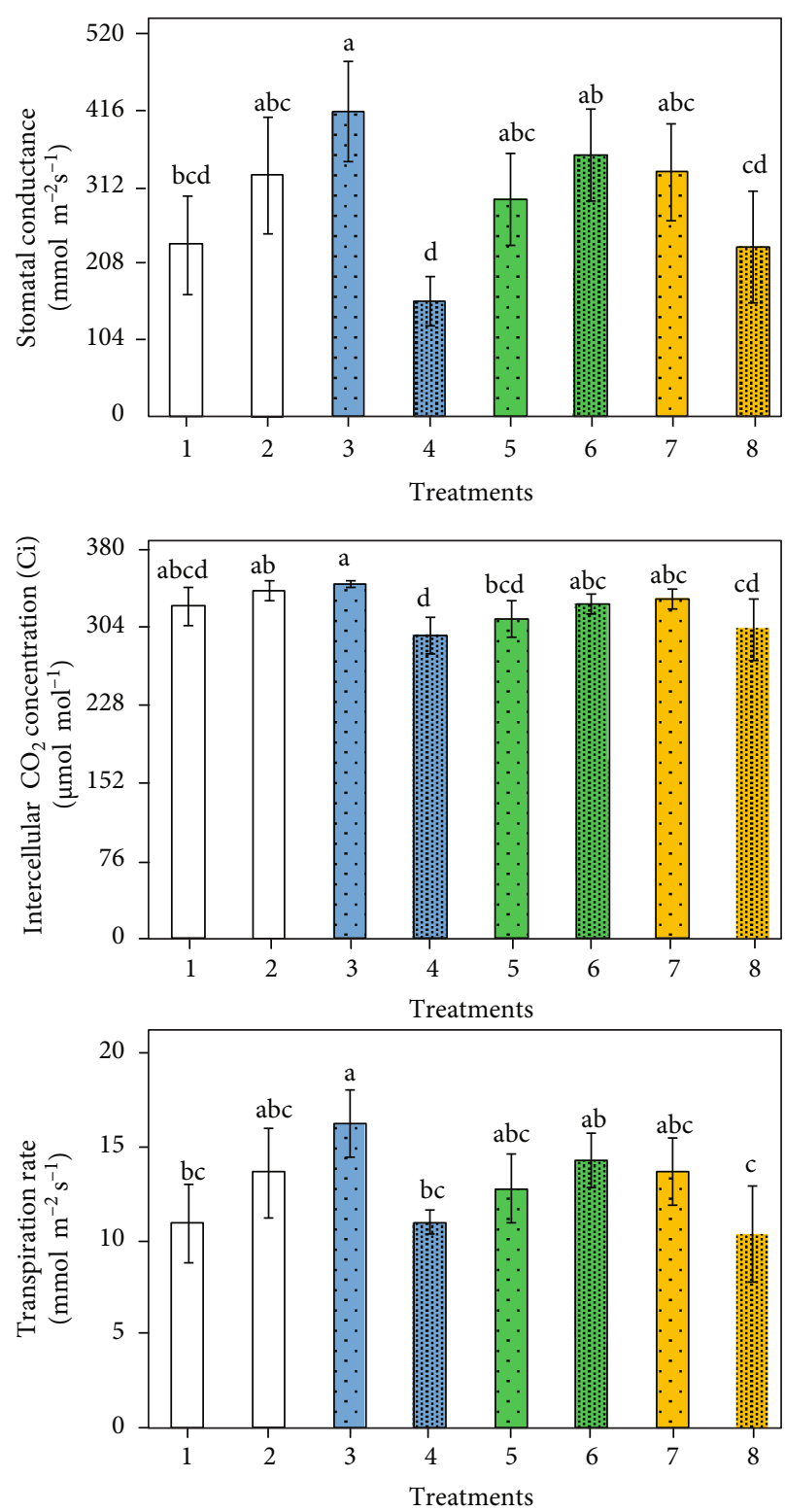

FIGURE 11: Stomatal conductance, intercellular $\mathrm{CO}_{2}$ concentration (Ci), and transpiration of rice plants cultivar Morelos A-2010 treated for $13 \mathrm{~d}$ with different sources and concentrations of $\mathrm{P}$. Means \pm SD with different letters in each subfigure are statistically different (LSD, $P \leq 0.05 ; n=9$ ). Treatments: $1=$ distilled water; $2=$ type A gel; $3=50 \%[\mathrm{P}]_{\text {Yoshida solution }}$ from $\mathrm{KH}_{2} \mathrm{PO}_{4} ; 4=100 \%$ $[\mathrm{P}]_{\text {Yoshida solution }}$ from $\mathrm{KH}_{2} \mathrm{PO}_{4} ; 5=50 \%[\mathrm{P}]_{\text {Yoshida solution }}$ from nano- $\mathrm{KH}_{2} \mathrm{PO}_{4} ; 6=100 \%[\mathrm{P}]_{\text {Yoshida solution }}$ from nano- $\mathrm{KH}_{2} \mathrm{PO}_{4}$; $7=50 \% \quad[\mathrm{P}]_{\text {Yoshida solution }}$ from nano- $\mathrm{KH}_{2} \mathrm{PO}_{4}$ with trypsin $\left(0.1 \mathrm{mg} \mathrm{L}^{-1}\right) ; 8=100 \%[\mathrm{P}]_{\text {Yoshida solution }}$ from nano- $\mathrm{KH}_{2} \mathrm{PO}_{4}$ with trypsin $\left(0.2 \mathrm{mg} \mathrm{L}^{-1}\right)$.

ability are determining criteria to be considered when designing protocols for industrial production [51].

\section{Conclusions}

Our results demonstrated that rice plants Morelos A-2010 displayed differential $\mathrm{P}$ uptake depending on the source of $\mathrm{P}$ used. Phosphorus supplied from $\mathrm{KH}_{2} \mathrm{PO}_{4}$ exhibited a 
higher absorption rate than $\mathrm{P}$ supplied from nano$\mathrm{KH}_{2} \mathrm{PO}_{4}$, alone or with trypsin. Importantly, the supply of $\mathrm{P}$ as nano- $\mathrm{KH}_{2} \mathrm{PO}_{4}$ promoted greater physiological efficiency of the shoots and roots for $\mathrm{P}$, with higher accumulations in these organs. $\mathrm{P}$ concentration in shoots, as well as its accumulation in shoots and roots, was positively related with the photosynthetic rate. Moreover, the treatment with nano- $\mathrm{KH}_{2} \mathrm{PO}_{4}$ increased the instant water use efficiency in rice plants.

The treatment applying 50\% of the recommended dose of $\mathrm{P}$ from nano- $\mathrm{KH}_{2} \mathrm{PO}_{4}$ resulted in a higher photosynthetic rate as compared to the treatment using $100 \%$ of $\mathrm{P}$ from conventional fertilizer. Therefore, the use of nano- $\mathrm{KH}_{2} \mathrm{PO}_{4}$ may allow reduce the quantity of applied fertilizer, lowering production costs and pollution risk.

Since $\mathrm{P}$ release was not immediate when using nano$\mathrm{K}_{2} \mathrm{HPO}_{4}$, a more efficient $\mathrm{P}$ absorption might have been induced possibly via high-affinity transporters, which finally lead to a higher physiological efficiency both in the shoots and in the roots in this treatment. Our research group is currently designing the strategies to prove this hypothesis.

\section{Data Availability}

The data used to support the findings of this study are available from the corresponding authors upon request.

\section{Disclosure}

The funder had no role in study design, data collection and analysis, decision to publish, or preparation of the manuscript.

\section{Conflicts of Interest}

The authors declare that there is no conflict of interests regarding the publication of this paper.

\section{Acknowledgments}

Authors are grateful to Mexico's National Science and Technology Council (CONACYT) for the scholarship given to EMV, as well as for the infrastructure and financial support provided to Colegio de Postgraduados Campus Montecillo.

\section{References}

[1] R. Nair, S. H. Varghese, B. G. Nair, T. Maekawa, Y. Yoshida, and D. S. Kumar, "Nanoparticulate material delivery to plants," Plant Science, vol. 179, no. 3, pp. 154-163, 2010.

[2] J. Kurepa, T. Paunesku, S. Vogt et al., "Uptake and distribution of ultrasmall anatase $\mathrm{TiO}_{2}$ Alizarin red $\mathrm{S}$ nanoconjugates in Arabidopsis thaliana," Nano Letters, vol. 10, no. 7, pp. 22962302, 2010.

[3] Z. Cifuentes, L. Custardoy, J. M. de la Fuente et al., "Absorption and translocation to the aerial part of magnetic carboncoated nanoparticles through the root of different crop plants," Journal of Nanobiotechnology, vol. 8, no. 1, pp. 26-28, 2010.

[4] I. O. Adisa, V. L. Reddy, J. R. Peralta-Videa et al., "Recent advances in nano-enabled fertilizers and pesticides: a critical review of mechanisms of action," Environmental Science: Nano, vol. 6, no. 7, pp. 2002-2030, 2019.

[5] H. Chen, "Metal based nanoparticles in agricultural system: behavior, transport, and interaction with plants," Chemical Speciation and Bioavailability, vol. 30, no. 1, pp. 123-134, 2018.

[6] F. C. Gómez-Merino and L. I. Trejo-Téllez, "The role of beneficial elements in triggering adaptive responses to environmental stressors and improving plant performance," in Biotic and Abiotic Stress Tolerance in Plantspp. 137-172, Springer Nature, Singapore.

[7] UNEP, "Emerging challenges-nanotechnology and the environment," in GEO Year Bookpp. 61-70, United Nations Environment Programme Division of Early Warning and Assessment, Nairobi.

[8] E. Vázquez-Núnez, M. L. López-Moreno, G. de la Rosa-Álvarez, and F. Fernández Luqueño, "Incorporation of nanopaticles into plant nutrients: the real benefits," in Agricultural Nanobiotechnology, F. López-Valdez and F. FernándezLuqueño, Eds., pp. 46-76, Springer, Cham, 2018.

[9] T. Aziz, M. Sabir, M. Farooq, M. A. Maqsood, H. R. Ahmad, and E. A. Warraich, "Phosphorus deficiency in plants: responses, adaptive mechanisms and signaling," in Plant Signaling: Understanding the Molecular Crosstalk, K. Hakeem, R. Rehman, and I. Tahir, Eds., pp. 133-148, Springer New Delhi, India, 2013.

[10] G. Alcántar-González, L. I. Trejo-Téllez, and F. C. GómezMerino, "Nutrición de Cultivos," Editorial del Colegio de Postgraduados Segunda edición, 2016.

[11] J. Shen, L. Yuan, J. Zhang et al., "Phosphorus dynamics: from soil to plant," Plant Physiology, vol. 156, no. 3, pp. 997-1005, 2011.

[12] D. S. Almeida, C. J. Penn, and C. A. Rosolem, "Assessment of phosphorus availability in soil cultivated with ruzigrass," Geoderma, vol. 312, pp. 64-73, 2018.

[13] J. J. Schröder, D. Cordel, A. L. Smit, and A. Rosemarinm, Sustainable Use of Phosphorus, 2009, http://ec.europa.eu/ environment/natres/pdf/phosphorus/sustainable_use_ phosphorus.pdf.

[14] J. M. Tolentino-Martínez, "La producción de arroz del estado de Morelos: una aproximación desde el enfoque SIAL," Estudios Sociales, vol. 22, no. 44, pp. 39-61, 2014.

[15] P. A. Seck, A. Diagne, S. Mohanty, and M. C. Wopereis, "Crops that feed the world 7: rice," Food Security, vol. 4, no. 1, pp. 724, 2012.

[16] P. Wu, H. Shou, G. Xu, and X. Lian, "Improvement of phosphorus efficiency in rice on the basis of understanding phosphate signaling and homeostasis," Current Opinion in Plant Biology, vol. 16, no. 2, pp. 205-212, 2013.

[17] S. Yoshida, D. A. Forno, J. H. Cook, and K. A. Gomez, "Routine procedures for growing rice plants in culture solution," in Laboratory Manual for Physiological Studies of Rice, pp. 61-66, IRRI, Los Banos, Philippines, 1976.

[18] J. Salcedo-Aceves and E. J. Barrios-Gómez, "Morelos A-2010, new rice variety for direct sowing for Central Mexico," Revista Mexicana de Ciencias Agrícolas, vol. 3, no. 7, pp. 1453-1458, 2012.

[19] T. Murashige and F. Skoog, "A Revised Medium for Rapid Growth and Bio Assays with Tobacco Tissue Cultures," Physiologia Plantarum, vol. 15, no. 3, pp. 473497, 1962. 
[20] E. Miranda-Villagómez, M. Á. Aguilar-Méndez, F. C. GómezMerino et al., "Synthesis of biopolymeric particles loaded with phosphorus and potassium: characterisation and release tests," IET Nanobiotechnology, vol. 13, no. 5, pp. 493-497, 2019.

[21] SAS, SAS User's Guide, SAS Institute Inc. Version 9.4. USA, Cary, NJ, USA, 2016.

[22] D. C. Gemenet, C. T. Hash, M. D. Sanogo et al., "Phosphorus uptake and utilization efficiency in West African pearl millet inbred lines," Field Crops Research, vol. 171, no. 2015, pp. 54-66, 2015.

[23] N. Mahanta, A. Dambale, and M. Rajkhowa, "Nutrient use efficiency through nano fertilizers," International Journal of Chemical Studies, vol. 7, no. 3, pp. 289-2842, 2019.

[24] E. E. Elemike, I. M. Uzoh, D. C. Onwudiwe, and O. O. Babalola, "The role of nanotechnology in the fortification of plant nutrients and improvement of crop production," Applied Sciences, vol. 9, no. 3, article 499, pp. 1-32, 2019.

[25] R. Liu and R. Lal, "Synthetic apatite nanoparticles as a phosphorus fertilizer for soybean (Glycine max)," Scientific Reports, vol. 4, no. 1, pp. 5686-5691, 2014.

[26] M. Rawat, P. Yadukrishnan, and N. Kumar, "Mechanisms of action of nanoparticles in living systems," in Microbial Biotechnology in Environmental Monitoring and Cleanup, pp. 220-236, IGI Global, India, 2018.

[27] S. G. Assuero, A. Mollier, and S. Pellerin, "The decrease in growth of phosphorus-deficient maize leaves is related to a lower cell production," Plant Cell and Environment, vol. 27, no. 7, pp. 887-895, 2004.

[28] M. Kavanová, F. A. Lattanzi, A. A. Grimoldi, and H. Schnyder, "Phosphorus deficiency decreases cell division and elongation in grass leaves," Plant Physiology, vol. 141, no. 2, pp. 766-775, 2006.

[29] J. Chiera, J. Thomas, and T. Rufty, "Leaf initiation and development in soybean under phosphorus stress," Journal of Experimental Botany, vol. 53, no. 368, pp. 473-481, 2002.

[30] A. Dobermann and T. H. Fairhurst, Nutrient disorders and nutrient management, Potash and Phosphate Institute, Potash and Phosphate Institute of Canada, and International Rice Research Institute, Singapore, 2000.

[31] R. C. Chaudhary and J. S. Nanda, Guía para identificar las limitaciones de campo en la producción de arroz, 2003, http://www .fao.org/docrep/006/y2778s/y2778s04.htm.

[32] F. Zhang, X. N. Wu, H. M. Zhou et al., "Overexpression of rice phosphate transporter gene OsPT6 enhances phosphate uptake and accumulation in transgenic rice plants," Plant and Soil, vol. 384, no. 1-2, pp. 259-270, 2014.

[33] W. Yan, G. H. Chen, L. F. Yang, J. Y. Gai, and Y. L. Zhu, “Overexpression of the rice phosphate transporter gene OsPT6 enhances tolerance to low phosphorus stress in vegetable soybean," Scientia Horticulturae, vol. 177, pp. 71-76, 2014.

[34] D. Luquet, B. G. Zhang, M. Dingkuhn, A. Dexet, and A. Clément-Vidal, "Phenotypic plasticity of rice seedlings: case of phosphorus deficiency," Plant Production Science, vol. 8, no. 2, pp. 145-151, 2005.

[35] J. Li, Y. Xie, A. Dai, L. Liu, and Z. Li, "Root and shoot traits responses to phosphorus deficiency and QTL analysis at seedling stage using introgression lines of rice," Journal of Genetics and Genomics, vol. 36, no. 3, pp. 173-183, 2009.

[36] C. Hermans, J. P. Hammond, P. J. White, and N. Verbruggen, "How do plants respond to nutrient shortage by biomass allo- cation?," Trends in Plant Science, vol. 11, no. 12, pp. 610-617, 2006.

[37] C. Ma, J. C. White, O. P. Dhankher, and B. Xing, "Metal-based nanotoxicity and detoxification pathways in higher plants," Environmental Science and Technology, vol. 49, no. 12, pp. 7109-7122, 2015.

[38] Z. Wang, X. Xie, J. Zhao et al., "Xylem- and phloem-based transport of $\mathrm{CuO}$ nanoparticles in maize (Zea mays L.)," Environmental Science and Technology, vol. 46, no. 8, pp. 44344441, 2012.

[39] M. G. Santos, V. R. Ribeiro, F. R. Oliverira, and C. Pimentel, "Gas exchange and yield response to foliar phosphorus application in Phaseolus vulgaris L. under drought," Brazilian Journal of Plant Physiology, vol. 16, no. 3, pp. 171-179, 2004.

[40] C. M. Rico, S. Majumdar, M. Duarte-Gardea, J. R. PeraltaVidea, and J. L. Gardea-Torresdey, "Interaction of nanoparticles with edible plants and their possible implications in the food chain," Journal of Agricultural and Food Chemistry, vol. 59, no. 8, pp. 3485-3498, 2011.

[41] Y. Ye, J. Yuan, X. Chang et al., "The phosphate transporter gene OsPht 1;4 is involved in phosphate homeostasis in rice," PLoS One, vol. 10, no. 5, article e0126186, 2015.

[42] B. Péret, M. Clément, L. Nussaume, and T. Desnos, "Root developmental adaptation to phosphate starvation: better safe than sorry," Trends in Plant Science, vol. 16, no. 8, pp. 442450, 2011.

[43] K. Jeong, N. Mattes, S. Catausan, J. H. Chin, U. Paszkowski, and S. Heuer, "Genetic diversity for mycorrhizal symbiosis and phosphate transporters in rice," Journal of Integrative Plant Biology, vol. 57, no. 11, pp. 969-979, 2015.

[44] H. Zhu, J. Han, J. Q. Xiao, and Y. Jin, "Uptake, translocation and accumulation of manufactured iron oxide nanoparticles by pumpkin plants," Journal of Environmental Monitoring, vol. 10, no. 6, pp. 713-717, 2008.

[45] E. J. Veneklaas, H. Lambers, J. Bragg et al., “Opportunities for improving phosphorus-use efficiency in crop plants," New Phytologist, vol. 195, no. 2, pp. 306-320, 2012.

[46] P. Ravi, B. Raj, and P. C. Rao, "Nutrient status and establishment of critical values and adequate ranges for different nutrients for rice (Oryza sativa L.) trough DRIS in Karimnagar District of Andhra Pradesh," International Journal of Developmental Research, vol. 3, no. 10, pp. 102-105, 2013.

[47] R. C. Warren, "How does P affect photosynthesis and metabolite profiles of Eucalyptus globulus?," Tree Physiology, vol. 31, no. 7, pp. 727-739, 2011.

[48] Y. F. Li, A. C. Luo, M. J. Hassan, and X. H. Wei, "Effect of phosphorus deficiency on leaf photosynthesis and carbohydrates partitioning in two rice genotypes with contrasting low phosphorus susceptibility," Rice Science, vol. 13, no. 4, pp. 283-290, 2006.

[49] N. Veronica, D. Subrahmanyam, T. Vishnu Kiran et al., "Influence of low phosphorus concentration on leaf photosynthetic characteristics and antioxidant response of rice genotypes," Photosynthetica, vol. 55, no. 2, pp. 285-293, 2017.

[50] R. Guo, S. Sun, and B. Liu, "Difference in leaf water use efficiency/photosynthetic nitrogen use efficiency of Bt-cotton and its conventional peer," Scientific Reports, vol. 6, article 33539, pp. 1-7, 2016.

[51] S. Nagula and P. B. Usha, "Application of nanotechnology in soil and plant system with special reference to nanofertilizers," Advances in Life Sciences, vol. 1, no. 14, pp. 5544-5548, 2016. 


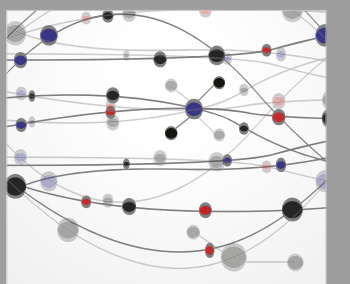

The Scientific World Journal
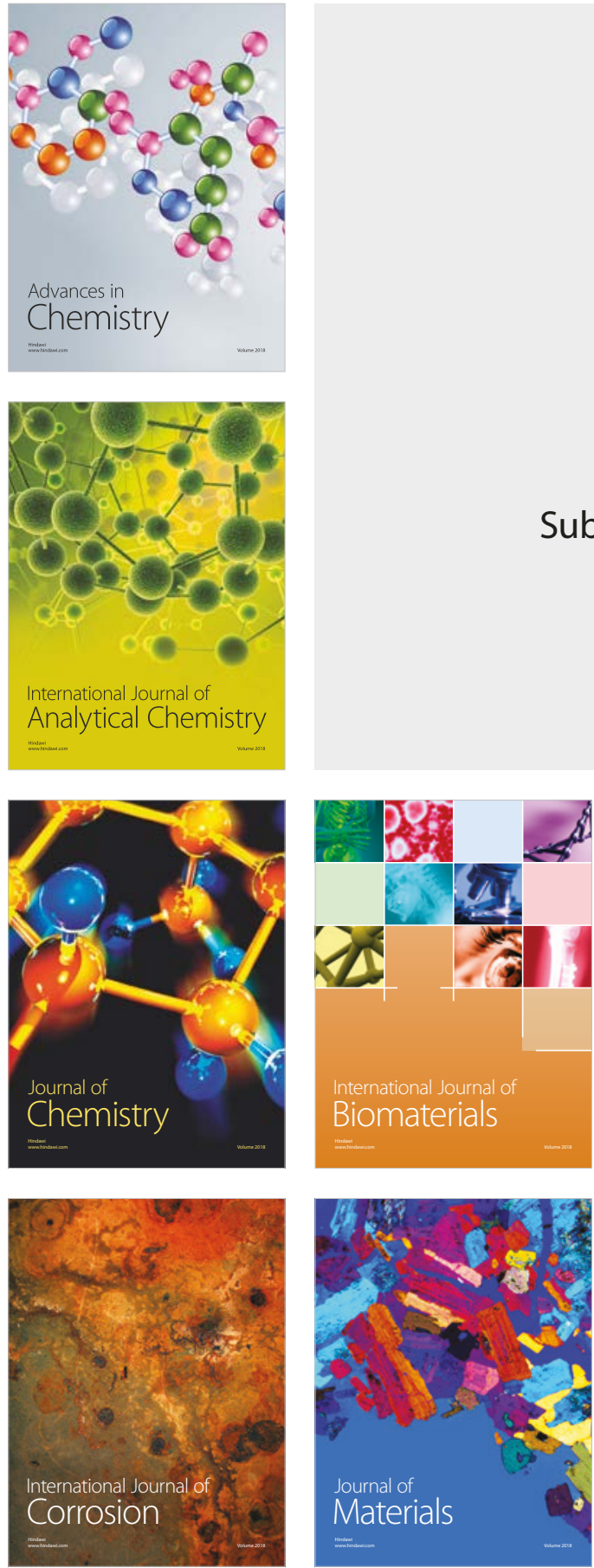

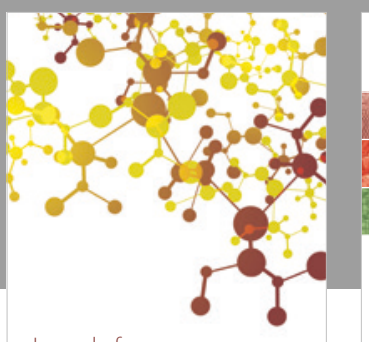

Journal of

Applied Chemistry
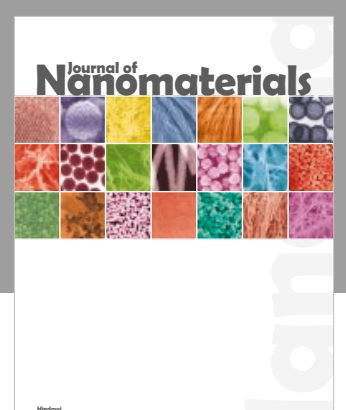

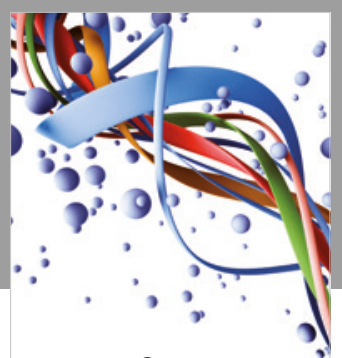

Scientifica

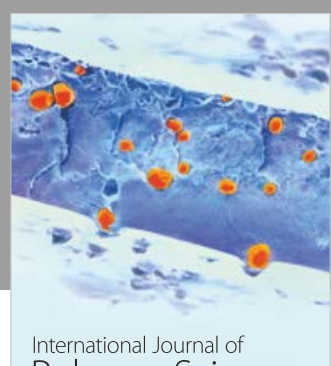

Polymer Science

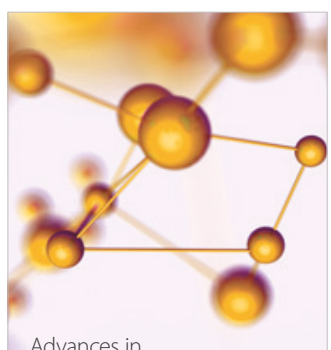

Physical Chemistry
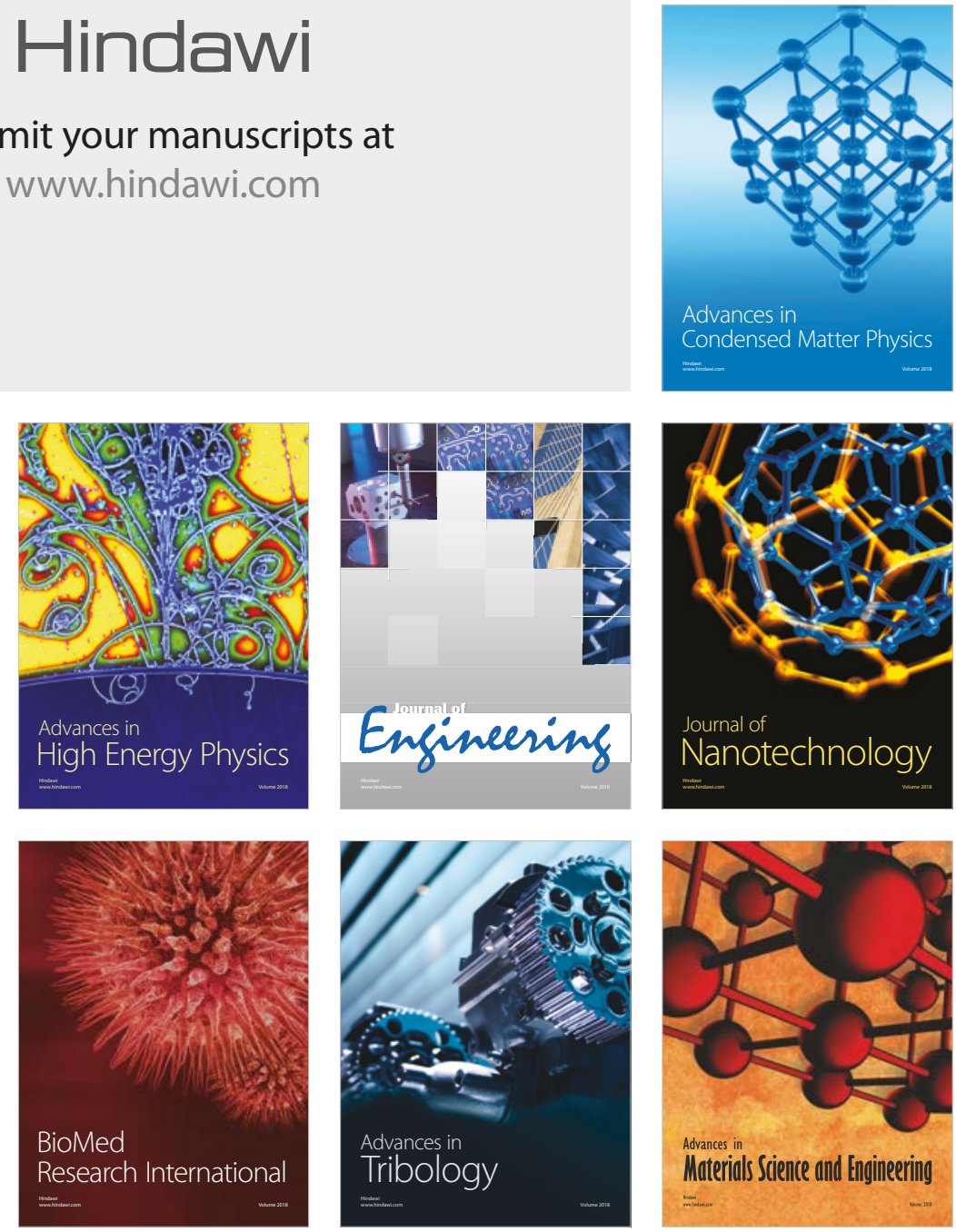